US Army Corps of Engineers ${ }_{\circledast}$

Engineer Research and

Development Center

Coastal Field Data Collection Program

\title{
Coastal Lidar and Radar Imaging System (CLARIS) Lidar Data Report
}

\section{1 - 2017}

Nicholas J. Spore, Alexander D. Renaud, Ian W. Conery, and Katherine L. Brodie

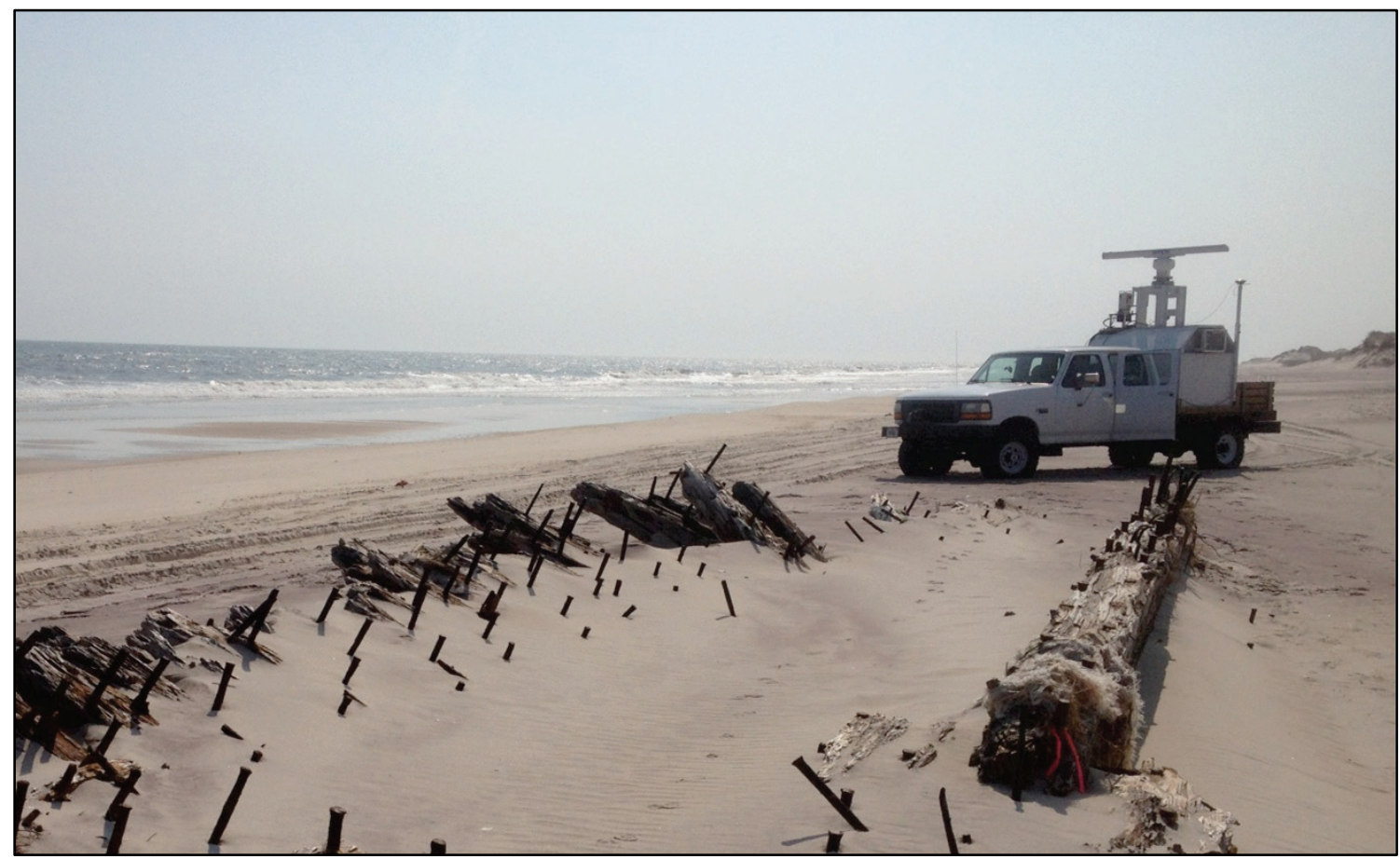


The U.S. Army Engineer Research and Development Center (ERDC) solves the nation's toughest engineering and environmental challenges. ERDC develops innovative solutions in civil and military engineering, geospatial sciences, water resources, and environmental sciences for the Army, the Department of Defense, civilian agencies, and our nation's public good. Find out more at www.erdc.usace.army.mil.

To search for other technical reports published by ERDC, visit the ERDC online library at http://acwc.sdp.sirsi.net/client/default. 


\section{Coastal Lidar and Radar Imaging System (CLARIS) Lidar Data Report}

\section{1-2017}

Nicholas J. Spore, Alexander D. Renaud, Ian W. Conery, and Katherine L. Brodie

Coastal and Hydraulics Laboratory

U.S. Army Engineer Research and Development Center

1261 Duck Road

Duck, NC 27949

Final report

Approved for public release; distribution is unlimited.

Prepared for Coastal Field Data Collection (CFDC) Program U.S. Army Engineer Research and Development Center Coastal and Hydraulics Laboratory Vicksburg, MS 39180-6199

Under Project 476930, “Remote Sensing” 


\section{Abstract}

This U.S. Army Corps of Engineers data report documents available terrestrial lidar datasets collected by the U.S. Army Engineer Research and Development Center, Coastal and Hydraulics Laboratory (CHL), Coastal Lidar and Radar Imaging System between 2011 and 2017 along the northern Outer Banks of North Carolina near the CHL Field Research Facility. The report briefly describes the system and study site as well as the survey data extents, collection dates, and environmental context and data access information for the point cloud and digital elevation model products. Initial morphology data products and initial analyses are presented including calculations of shoreline change, dune volume, beach volume, beach slope, and cumulative elevation change over the 6-year study period. Follow-on reports will update the description of the available data repository moving forward.

DISCLAIMER: The contents of this report are not to be used for advertising, publication, or promotional purposes. Citation of trade names does not constitute an official endorsement or approval of the use of such commercial products. All product names and trademarks cited are the property of their respective owners. The findings of this report are not to be construed as an official Department of the Army position unless so designated by other authorized documents. 


\section{Contents}

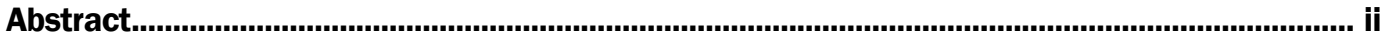

Figures and Tables......................................................................................................................................

Preface .............................................................................................................................................. vili

1 Introduction............................................................................................................................... 1

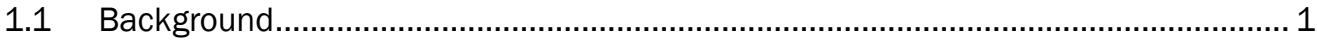

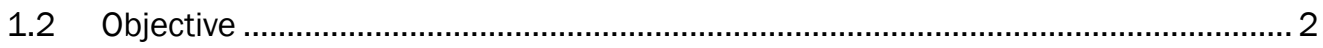

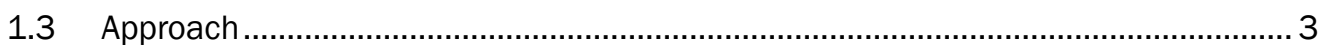

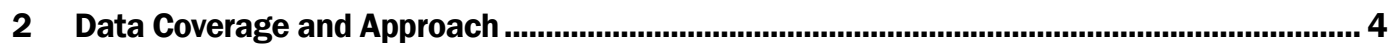

2.1 System features and operations ..................................................................... 4

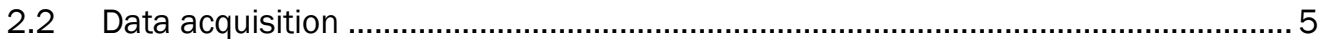

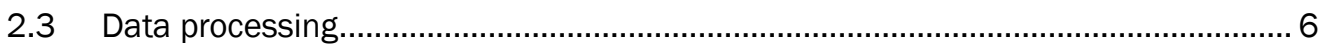

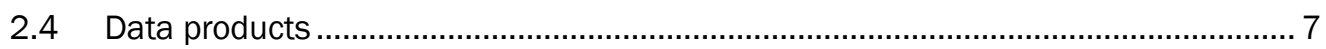

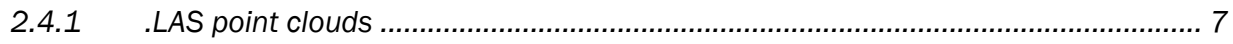

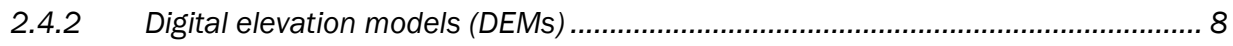

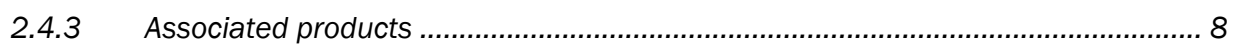

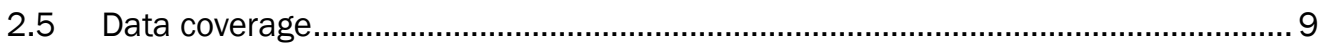

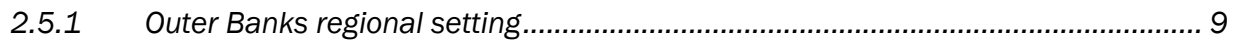

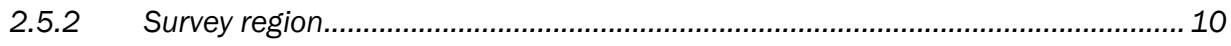

2.5.3 Temporal frequency ...................................................................................... 10

3 Environmental Conditions .............................................................................................13

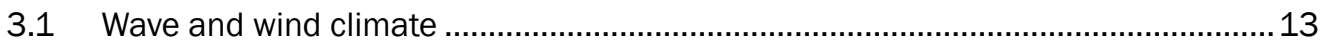

3.2 Storm events.......................................................................................... 15

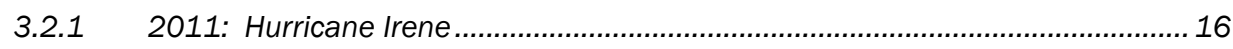

2012: Hurricane Sandy .............................................................................. 17

3.2.3 2013: March 2013 nor'easter.................................................................... 17

2014: Hurricane Arthur ..................................................................................... 18

3.2.5 2015: Hurricane Joaquin/nor'easter (early Oct 2015) ...................................... 19

2016: Winter 2016 nor'easters ......................................................................... 20

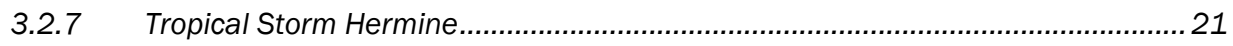

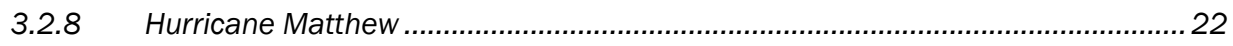

4 Coastal Lidar and Radar Imaging System (CLARIS) Data ...............................................23

4.1 Parametric and statistic calculations ................................................................ 23

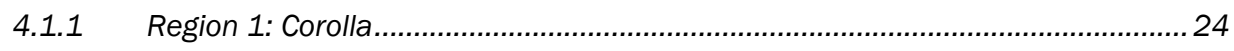

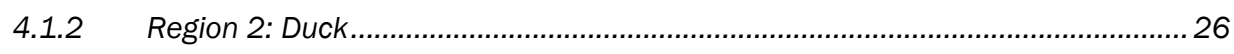

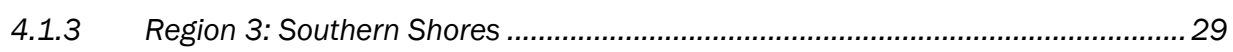

4.1.4 Kitty Hawk/Kill Devil Hills .............................................................................. 32

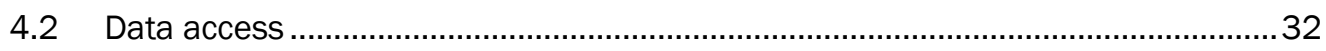

5 Conclusion........................................................................................................................................3 


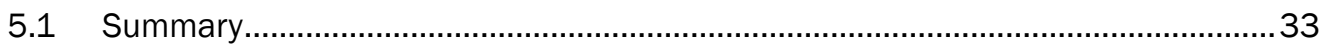

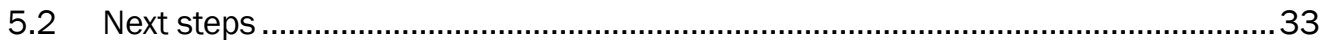

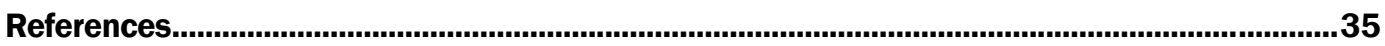

Report Documentation Page 


\section{Figures and Tables}

\section{Figures}

Figure 2-1. Data acquired for this report was collected with the F350 platform............................. 4

Figure 2-2. Concept of operations for TLS scanning on a beach. ..................................................... 6

Figure 2-3. CLARIS point cloud from 26 August 2016 of FRF property looking northwest................. 8

Figure 2-4. Spatial extent of CLARIS surveys between 2011 and 2017. The highlighted beach sections depict regional coordinate systems for evaluating changes in contour migration and volume changes. Several common start/ending points for CLARIS surveys of different areas/lengths are labeled. DEM based on 2014 NOAA Post-Sandy topobathymetric lidar collected by NOAA National Geodetic Survey Remote Sensing Division using a RiegI VQ820G system, acquired from 201311- 201406. Spatial References Vertical - North American Vertical Datum of 1988. Horizontal- NAD 1983 State Plane Coordinate System, Zone 3200.

Figure 2-5. CLARIS coverage alongshore (horizontal axis) through time (vertical axis), including named storms impacting the Outer Banks and unnamed storm events (mainly nor'easters) that had significant wave heights over $3 \mathrm{~m}$ (as measured at the FRF $17 \mathrm{~m}$ Waverider buoy) lasting over 8 hours. Spindrift Trail is in the Pine Island Community in Corolla, NC. The FRF is in Duck, NC. E. Dogwood Trail is in Southern Shores, NC. Avalon Pier is in northern Kill Devil Hills, NC.

Figure 3-1. Mean significant wave height $\left(\mathrm{H}_{\mathrm{s}}\right)$ at the $17 \mathrm{~m}$ Waverider buoy with CLARIS surveys noted in dashed vertical lines incrementing through time from blue to red. These colors correspond to the profile evolution figures presented in Chapter 4.

Figure 3-2. Wave rose of significant wave height at the $17 \mathrm{~m}$ Waverider buoy for 20112017.

Figure 3-3. Wind rose of winds recorded at the end of FRF pier for 2011-2017.

Figure 3-4. Significant wave height $\left(\mathrm{H}_{\mathrm{s}}\right)$ in meters (blue) and wave period during Hurricane Irene.

Figure 3-5: Significant wave height $\left(\mathrm{H}_{\mathrm{s}}\right)$ in meters (blue) and wave period during Hurricane Sandy.

Figure 3-6. Significant wave height $\left(\mathrm{H}_{\mathrm{s}}\right)$ in meters (blue) and wave period during a 2013 March nor'easter.

Figure 3-7. Significant wave height $\left(\mathrm{H}_{\mathrm{s}}\right)$ in meters (blue) and wave period during Hurricane Arthur.

Figure 3-8. Significant wave height (Hs) in meters (blue) and wave period during Hurricane Joaquin/nor'easter.

Figure 3-9. Significant wave height $\left(\mathrm{H}_{\mathrm{s}}\right)$ in meters (blue) and wave period during a January 2016 nor'easter.

Figure 3-10. Significant wave height $\left(\mathrm{H}_{\mathrm{s}}\right)$ in meters (blue) and wave period during a February nor'easter.

Figure 3-11. Significant wave height $\left(\mathrm{H}_{\mathrm{s}}\right)$ in meters (blue) and wave period during Tropical Storm Hermine.

Figure 3-12. Significant wave height $\left(\mathrm{H}_{\mathrm{s}}\right)$ in meters (blue) and wave period during Hurricane Matthew.

Figure 4-1. (left) Linear fit of dune volume change per year at each along-shore transect colored by the coefficient of determination $\left(R^{2}\right)$. Points that are grey colored had $p$-values 
greater than 0.05; (center) Average dune crest ( $\left(\mathrm{h}_{\mathrm{hi}}\right)$, dune toe ( $\mathrm{D}_{\mathrm{lo}} 3 \mathrm{~m}$ contour), and shoreline (shore $1 \mathrm{~m}$ contour) cross-shore position with $+/$ - one standard deviation shaded; legend at the bottom corresponds to the center panel; (right) Linear fit of shoreline cross-shore position change per year at each alongshore transect color by the coefficient of determination $\left(R^{2}\right)$. All panels correspond to the Corolla beach segment data of the northern Outer Banks surveyed by CLARIS.

Figure 4-2. Cumulative elevation change along the Corolla beach segment of the northern Outer Banks between 2011 and 2017.

Figure 4-3. Average dune and beach volume for transects within the Corolla beach segment. Dune volume was defined at each $2 \mathrm{~m}$ cross-shore transect as the area under the curve between dune crest and the $3 \mathrm{~m}$ contour. Beach volume defined as volume between the shoreline ( $1 \mathrm{~m}$ contour) and dune toe ( $3 \mathrm{~m}$ contour) for each $2 \mathrm{~m}$ wide transect.

Figure 4-4. Average dune and beach slope for transects within the Corolla beach survey segment Beach slope was calculated between the dune tow $\left(D_{l o}\right)$ defined at the $3 \mathrm{~m}$ contour and the shoreline, defined at the $1 \mathrm{~m}$ contour.

Figure 4-5. (left) Linear fit of dune volume change per year at each alongshore transect colored by the coefficient of determination $\left(R^{2}\right)$; (center) Average dune crest $\left(D_{h i}\right)$, dune toe (Dı $3 \mathrm{~m}$ contour), and shoreline (shore $1 \mathrm{~m}$ contour) cross-shore position with +/- one standard deviation shaded; legend at the bottom corresponds to the center panel; (right) Linear fit of shoreline cross-shore position change per year at each alongshore transect color by the coefficient of determination $\left(\mathrm{R}^{2}\right)$. All panels correspond to the Duck beach segment data of the northern Outer Banks surveyed by CLARIS.

Figure 4-6. Cumulative elevation change along the Duck beach segment of the northern Outer Banks between 2011 and 2017. For reference, the FRF pier is located at $3700 \mathrm{~m}$ along-shore within the regional Duck beach segment coordinate system.

Figure 4-7. Average dune and beach volume for transects within the Duck beach segment. Dune volume was defined at each $2 \mathrm{~m}$ cross-shore transect as the area under the curve between dune crest and the $3 \mathrm{~m}$ contour. Beach volume defined as volume between the shoreline ( $1 \mathrm{~m}$ contour) and dune toe ( $3 \mathrm{~m}$ contour) for each $2 \mathrm{~m}$ wide transect.

Figure 4-8. Average dune and beach slope for transects within the Duck beach survey segment. Beach slope was calculated between the dune tow $\left(D_{1 \circ}\right)$ defined at the $3 \mathrm{~m}$ contour and the shoreline, defined at the $1 \mathrm{~m}$ contour.

Figure 4-9. (left) Linear fit of dune volume change per year at each alongshore transect colored by the coefficient of determination $\left(R^{2}\right)$; (center) Average dune crest $\left(D_{h i}\right)$, dune toe ( $D_{1 \circ} 3 \mathrm{~m}$ contour), and shoreline (shore $1 \mathrm{~m}$ contour) cross-shore position with +/- one standard deviation shaded; legend at the bottom corresponds to the center panel; (right) Linear fit of shoreline cross-shore position change per year at each alongshore transect color by the coefficient of determination $\left(\mathrm{R}^{2}\right)$. All panels correspond to the Southern Shores beach segment data of the northern Outer Banks surveyed by CLARIS.

Figure 4-10. Cumulative elevation change along the Southern Shores beach segment of the northern Outer Banks between 2011 and 2017.

Figure 4-11. Average dune and beach volume for transects within the Southern Shores beach segment. Dune volume was defined at each $2 \mathrm{~m}$ cross-shore transect as the area under the curve between dune crest and the $3 \mathrm{~m}$ contour. Beach volume defined as volume between the shoreline ( $1 \mathrm{~m}$ contour) and dune toe ( $3 \mathrm{~m}$ contour) for each $2 \mathrm{~m}$ wide transect. 
Figure 4-12. Average dune and beach slope for transects within the Southern Shores beach survey segment. Beach slope was calculated between the dune tow $\left(D_{l_{0}}\right)$ defined at the $3 \mathrm{~m}$ contour and the shoreline, defined at the $1 \mathrm{~m}$ contour.

\section{Tables}

Table 2-1. Riegl VZ-1000 TLS system specifications. ………..................................................... 5

Table 2-2. Applanix POS-LV 220 INS system accuracy specifications ............................................... 5

Table 3-1. Summary of extreme events with significant wave values surpassed $3 \mathrm{~m}$ for more than 8 hours. Values taken from $17 \mathrm{~m}$ Datawell Waverider buoy with any gaps filled in with data from the $11 \mathrm{~m}$ AWAC. *Note: 1/24/2016 is the second peak of that nor'easter. The above period durations only capture the peaks of wave events and in most cases still have significant wave energy remaining on either side of these. 


\section{Preface}

This report was funded by the U.S. Army Corps of Engineers (USACE) Coastal Field Data Collection (CFDC) Program, Project 476930, "Remote Sensing." The CFDC is administered at the U.S. Army Engineer Research and Development Center (ERDC), Coastal and Hydraulics Laboratory (CHL), under the Flood Risk Management (FRM) Business Line. Mr. Mark S. Roupas, Headquarters, USACE, was FRM Business Line Manager overseeing CFDC. Dr. Julie D. Rosati was the Technical Director of the FRM R\&D Programs. Dr. Jeffrey P. Waters, Coastal Observations and Analysis Branch, was Program Manager of CFDC.

The work was performed by the Coastal Observations and Analysis Branch of the Flood and Storm Protection Division, ERDC-CHL. Technical reviews and discussions of this report were provided by Ms. Eve R. Eisemann and Mr. Michael F. Forte of ERDC-CHL. At the time of publication of this report, Dr. Jeffrey P. Waters was Chief, Coastal Observations and Analysis Branch, and Dr. Cary A. Talbot was Chief, Flood and Storm Protection Division. Mr. Jeffrey R. Eckstein was the Deputy Director of ERDC-CHL, and the Director was Dr. Ty V. Wamsley.

COL Ivan P. Beckman was the Commander of ERDC, and the Director was Dr. David W. Pittman. 


\section{Introduction}

\subsection{Background}

The dynamic nature of the nation's coastlines necessitates frequent shoreline monitoring and mapping. The U.S. Army Engineer Research and Development Center, Coastal and Hydraulics Laboratory (CHL), Field Research Facility (FRF), has collected datasets on the nearshore zone's changing conditions for over 40 years (Birkemeier and Holland 2001). During the course of these efforts, CHL has continued to develop different technologies to refine shoreline monitoring techniques, with a particular focus on the application of remote sensing technology to coastal monitoring. Light detection and ranging (lidar) scanners have proven useful for the CHL coastal measurement efforts, providing highly detailed data of coastal change and hydrodynamic processes (O'Dea et al. 2019; Brodie et al. 2012; Brodie et al. 2015; Brodie et al. 2018a; Brodie et al. 2018b).

Lidar is frequently collected from stationary ground-based platforms, which provide fine detail (100s to 1000 s of points per meter) in one location or mobile airborne sampling approaches that provide coverage over large areas but at lower resolution (1 to 1 os of points per meter). The U.S. Army Corps of Engineers (USACE), U.S. Naval Oceanographic Office, and National Oceanic and Atmospheric Administration (NOAA) formed the Joint Airborne Lidar Bathymetry Technical Center of eXpertise in 1998 to support coastal mapping requirements and committed to surveying the U.S. coastline every 5 years with airborne lidar (Sylvester 2012). As a result of these and other efforts, coastal monitoring with airborne lidar data has provided a range of insights into coastal change since the late 1990 (e.g., Irish and White 1998; Sallenger et al. 2003; Wozencraft and Lillycrop 2003; Gares et al. 2006; Brock and Purkis 2009; Earlie et al. 2015; Pye and Blott 2016; Robertson et al. 2018; Eisemann et al. 2018). While airborne lidar sampling provides significant coverage, it also demands significant resources for deployment and may lack the temporal and spatial resolution necessary to adequately map the evolution of coastal features at scales relevant to the forcing conditions (Young et al. 2010; La Mauff et al. 2018; Pietro et al. 2008). To bridge the gap between airborne lidar coverage and terrestrial lidar scanner resolution and ease of deployment, CHL developed the Coastal Lidar and Radar Imagining System (CLARIS), a mobile, truck-based lidar system that can survey $10 \mathrm{~s}$ 
of kilometers of coast at high-resolution (100s to 1000s of points per meter) in 1 day.

Mobile, terrestrial-based lidar systems offer the benefits of traditional stationary high-resolution scanning, and given a high-precision inertial navigation system, allow for large regional surveys to be conducted within hours at comparable resolution (Spore and Brodie 2017). CHL utilizes CLARIS to monitor beach elevation throughout the year on seasonal scale as well as before, during, and after extratropical, subtropical, and tropical storms or hurricanes. The regular, frequent collection along the same segments of shoreline reduces the uncertainty that often accompanies more sporadic, interannual beach surveys (Le Mauff et al. 2018).

Frequent high-resolution sub-aerial beach topographic surveys are critical to understanding variability of beach morphological evolution across different time-scales. Continued data collection can support scaling observations between these shorter events, seasonal, or year-length fluctuations to decadal scale change. The observational data can also be used to directly assess the condition of dunes and other natural coastal infrastructure. For example, Brodie and Spore (2015) compared CLARIS data against insight from Hesp (2002) to classify dune health by measuring their slopes, volumes, and curvature. The data will also support the development of better models for wave runup, coastal inundation, and overall sediment transport by providing more data for model input and validation, particularly across larger, regional scales.

\subsection{Objective}

The objective of this data report is to document the data collected by the CHL mobile terrestrial lidar surveying system from 2011-2017 and provide information on the associated major storm events that impacted the area during this time, to facilitate the use of the data for research. No scientific interpretation of observed coastal evolution is provided; however, analysis plots of coastal change are included to help the reader identify interesting time-periods or locations for further research. Radar data have not been included in this report due to system complications and continued research and development. Following this introduction, Chapter 2 summarizes the CLARIS system and data collection approach. Chapter 3 provides context for the data collection in the form of extreme events, wave climate, and related conditions that shape morphological response along the northern Outer Banks. Chapter 4 presents summary statistics for 
the different CLARIS datasets, focusing on changes in shoreline, volume, slope, and dunes. Chapter 5 concludes the data report and provides insight into the new 2017 CLARIS vehicle and measuring the 2017 northern Outer Banks beach nourishment.

\subsection{Approach}

The approach is addressed in Chapter 2, Data Coverage and Approach. 


\section{Data Coverage and Approach}

This chapter provides a brief overview of the collection system, the study region, operational and data processing procedures, and the data products. This report details the range of dates and area covered by 20112017 surveys. More in-depth details regarding the overall development of the system have been described by Spore and Brodie (2017).

\subsection{System features and operations}

Data collection of the sub-aerial beach before, during, and after coastal storms presents a challenging environment for vehicular trafficability and sensitive instrumentation. Since 2009, research and development of an accurate and robust data acquisition vehicle has led to a progression of platforms.

This report focuses on data collected from 2011 until 2017 aboard a Ford F350 pickup truck (Figure 2-1). The F350 provided a powerful motor with good low-end torque, adequate for off-road driving in loose sand. Shortcomings included vehicle weight, long wheelbase, and overall mechanical integrity due to its age. The instrumentation specifics are outlined on the following page (Table 2-1).

Figure 2-1. Data acquired for this report was collected with the F350 platform.

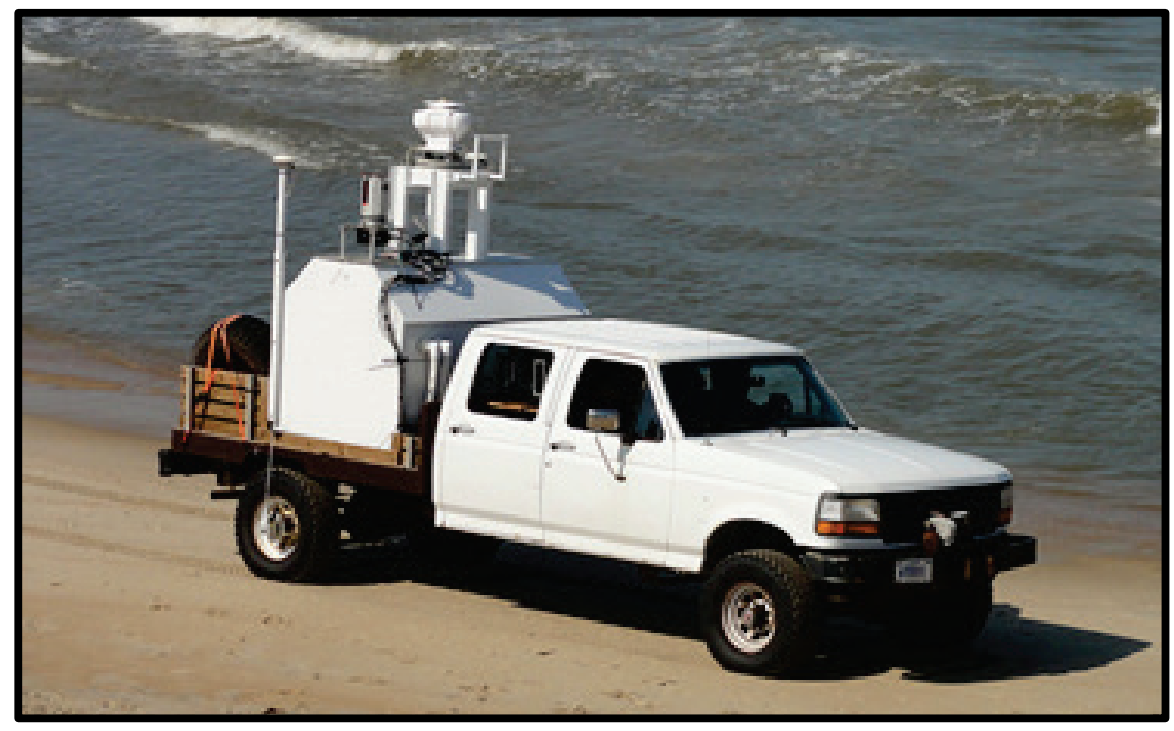


- Riegl VZ-100o Terrestrial Lidar Scanner (TLS); class 1 laser

Table 2-1. RiegI VZ-1000 TLS system specifications.

\begin{tabular}{|l|l|}
\hline Laser Wavelength & $\begin{array}{l}1550 \text { nanometers } \\
\text { (near infrared) }\end{array}$ \\
\hline Range & $2.5-1400$ meters $(\mathrm{m})$ \\
\hline Horizontal Angular Stepwidth Resolution & $0.0024-0.5$ degrees \\
\hline Vertical Angular Stepwidth Resolution & $0.0024-0.288$ degrees \\
\hline Accuracy & $8 \mathrm{~mm}$ \\
\hline Precision & $5 \mathrm{~mm}$ \\
\hline
\end{tabular}

- Applanix POS-LV 220 Inertial Navigation System (INS) with integrated inertial measurement unit, distance measurement instrument (DMI), and two global navigation satellite system (GNSS/GPS) antennas. The published accuracy of the system, as stated by the manufacturer, is shown in Table 2-2.

Table 2-2. Applanix POS-LV 220 INS system accuracy specifications

\begin{tabular}{|l|l|}
\hline Minimum Root Mean Square (RMS) Error (Post-Processed Solution) \\
\hline Horizontal (X,Y) Position & $0.020 \mathrm{~m}$ \\
\hline Vertical (Z) Position (m) & $0.050 \mathrm{~m}$ \\
\hline Roll and Pitch (deg) & 0.020 degrees \\
\hline True Heading (deg) & 0.250 degrees \\
\hline
\end{tabular}

- SiTek 4kW X-Band Radar with 2-degree beam width capable of at least 1 kilometer $(\mathrm{km})$ range

- Three mobile acquisition computer systems with solid-state hard drives

- Riegl RiAcquire software for acquiring and displaying data flow in real time

- Applanix POSView software for controlling and analyzing the INS trajectory metrics

- Custom-designed analogue-to-digital conversion card for processing radar intensity data

\subsection{Data acquisition}

Three-dimensional (3D) topographic elevations are acquired with the VZ-100o TLS coupled with the Position and Orientation System for Land 
Vehicles (POS-LV) INS for timing and positioning the data. The VZ-10oo TLS operates as a two-dimensional (2D) range finder that obtains the third-dimension as the vehicle advances forward. This approach requires transiting the study site in two passes: one facing the shoreline with the truck navigating near the dune toe and the other facing the dune with the truck navigating near the shoreline (Figure 2-2). The overlap ensures continuous data overlap throughout the study site and results in nearseamless data coverage from the shoreline to the dune crest. All surveys are centered on low tide to maximize data coverage of the exposed foreshore. Typical beach driving speed is $10-20 \mathrm{~km} /$ hour depending on conditions, which results in approximately $20 \mathrm{~km}$ of coverage over a 4 hour window centered on low tide.

Each data collection also incorporates an independent acquisition of various sized planar features (e.g., buildings, roads) within the FRF used for the boresight alignment, which aligns the scanner orientation and position relative to the fixed INS measurement center. The TLS and INS are also boresighted for each survey to account for any subtle changes to the sensor mounts. An accuracy assessment of the system was performed in Spore and Brodie (2017) over 10 separate surveys and found 0.075 meter (m) RMS horizontal error and $0.099 \mathrm{~m}$ RMS vertical error for 20 spatially distributed control points.

Figure 2-2. Concept of operations for TLS scanning on a beach.

Scancererage (30)

\subsection{Data processing}

To create geo-rectified point clouds, trajectory data (position and attitude) of the vehicle are post-processed utilizing position corrections from a local National Geodetic Survey (NGS) Continuously Operating Reference Station (CORS). Vendor-supplied software utilizes a forward and backward Kalman filter to produce a best-estimate trajectory file for the lidar, combining data from the GPS, INS, and DMI. The trajectory data are 
then time-matched and applied to the scans to estimate a boresight alignment between the TLS and INS. The boresight alignment uses a plane-matching algorithm that minimizes errors through a least squares fit of successive measurements of the same plane through different scanning angles (France and Butler 2012; Rieger et. al 2010). Finally, the trajectory and boresight alignment parameters are applied to the spatial point data resulting in a geo-rectified point cloud. Additional specific details regarding the processing methodology are outlined in Chapter 3 of Spore and Brodie (2017).

\subsection{Data products}

Following data collection, processing, and QA/QC, CLARIS data are used to generate .LAS point clouds, digital elevation models (DEMs), and a suite of associated products described below.

\subsection{1 .LAS point clouds}

CLARIS point clouds (e.g., Figure 2-3) are filtered to separate ground, non-ground, and water points. The beach-water interface is manually determined and cleaned to remove non-ground data points. Riegl's proprietary RiPROCESS software is used to filter terrestrial point cloud points based on the following parameters: base grid size, number of levels used in process, tolerance factor (cutoff planes for data), percentile (number of points within a cell that are below representative cell point to define a cell's local surface), and maximum slope angle. More filtering specifics are outlined in section 5.1 of Spore and Brodie (2017). Following marking of "unclassified" non-ground points (e.g., vegetation, sand fencing), the point cloud is exported as a single .LAS file or multiple, tiled .LAS or .LAZ files. 
Figure 2-3. CLARIS point cloud from 26 August 2016 of FRF property looking northwest.

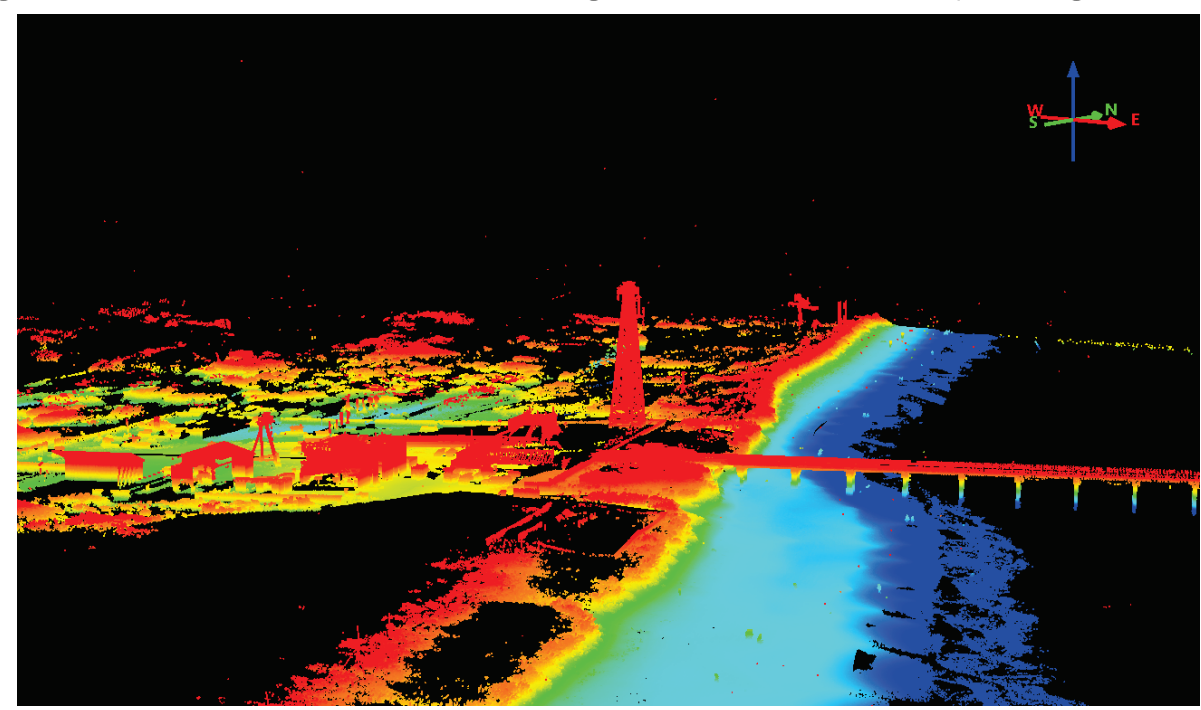

\subsubsection{Digital elevation models (DEMs)}

DEMs are derived from the ground-classified points within filtered and classified point clouds. For the purposes of this report, points are gridded at $0.5 \mathrm{~m}$ resolution in the cross-shore and $2 \mathrm{~m}$ in the along-shore using a nearest neighbor interpolation algorithm. This technique does not fill holes or data gaps spatially within the grid in an effort to preserve the in situ data as much as possible. As with any interpolation routine, some error is introduced into the final DEM, as the gridded cell size is typically larger than the point-spacing within the classified point cloud. Spatial error may be observed in sharp slope breaks and discontinuities such as at the foot of vertical beach and dune scarps, steep-faced (near vertical) foredunes, and dune crest position (e.g., see Figure 15 in Spore and Brodie [2017]).

\subsubsection{Associated products}

Point clouds and DEMs can be used in a variety of ways to assess the influence of coastal processes on the surrounding morphology. Chapter 4 details a number of these products for the 2011-2017 CLARIS datasets. These include maps characterizing elevation change through time, beach slope, shoreline migration, and average dune and beach volume with associated temporal trends. 


\subsection{Data coverage}

\subsubsection{Outer Banks regional setting}

The long and narrow barrier islands of the northern Outer Banks are typical of wave dominated, microtidal systems (Hayes 1979). Mean significant wave height is $1.0 \pm 0.6 \mathrm{~m}$ and tides are semi-diurnal with a mean range of $\sim 1 \mathrm{~m}$ (Lee et al. 1998). The coastal system is subject to high wave energy from extratropical storms, which typically occur in the winter and spring months, and tropical cyclones in the summer and fall. To protect the roadway and inland infrastructure from overwash, artificial sand dunes were constructed throughout the entire region in the 1930s and 1940s (Birkemeier et al. 1984). Section 3 provides more details on the environmental conditions for the region during the time period covered here.

The overall shoreline along the northern Outer Banks primarily faces northeast, with the orientation of beach segments ranging 15 to 30 degrees west of north from Corolla to Kitty Hawk (Figure 2-4). Net longshore transport is from north to south due to the high frequency and duration of extratropical storms from the northeast (i.e., nor'easters) (Dolan et al. 1988; Safak et al. 2017). Beach width is highly variable across the survey region but generally ranges from 20 to $30 \mathrm{~m}$ and fluctuates seasonally. At the FRF, Pianca et al. (2015) showed shoreline change $(-0.81 \pm 0.65 \mathrm{~m} /$ year) at long time-scales (26 years) dominates seasonal variability in shoreline position. Across all of Duck, from 1996 to 2012, the shoreline eroded at $-0.45 \mathrm{~m} /$ year (CPE 2016). To the south, higher erosion rates exceeding $-\mathbf{1 . 5} \mathrm{m} /$ year have been measured at longterm erosional hotspots in Kitty Hawk and Kill Devil Hills, which have been associated with the presence of paleochannels and associated shoreoblique bars offshore (Miselis and McNinch 2006; Safak et al. 2017).

Sediment grain size is highly variable temporally and in the cross-shore dimension. At Duck, the grain size distribution is bimodal, with means typically ranging from 0.25 to $0.45 \mathrm{~mm}$ (Birkemeier 1985; CPE 2015). Sediment size is generally coarsest at the energetic swash zone and decreases landward. Grain size has been shown to decrease from north to south in the study region due to the presence of gravels from the former Albemarle River Paleochannel toward the north (Birkemeier et al. 1985). In Duck, coarse lag deposits with means ranging from 0.6 to $0.8 \mathrm{~mm}$ have been measured on the foreshore (Birkemeier et al. 1985). 


\subsubsection{Survey region}

Between 2012 and 2017, CLARIS surveys were primarily conducted near the FRF, located in the town of Duck in the northern Outer Banks. Most surveys were focused within the towns of Corolla, Duck, and Southern Shores. Over time, the survey extent has been expanded to include Kitty Hawk, Kill Devil Hills, and Nags Head. From 2011 to 2017, the survey coverage ranged from 10 to $30 \mathrm{~km}$ and has historically been limited by the ability to fully cover the whole beach within 2 hours of low tide.

\subsubsection{Temporal frequency}

CLARIS surveys have been collected quarterly since 2013 when a regional monitoring program was established at the FRF. Prior to 2013, CLARIS surveys were primarily conducted around storm events (including during storms). Additional pre/post storm surveys are also conducted to supplement the present-day quarterly monitoring program. Figure 2-5 depicts the data coverage of CLARIS surveys through time relative to significant wave events (here defined as those with significant wave height peaks exceeding $3 \mathrm{~m}$ for more than 8 hours) impacting the Outer Banks from late 2011 through the beginning of 2017. The length of the orange bars represents the relative length of the CLARIS survey, ranging from Pine Island in Currituck County in the North and Avalon Pier in Kill Devil Hills in the South, with the FRF pier in the center. 
Figure 2-4. Spatial extent of CLARIS surveys between 2011 and 2017. The highlighted beach sections depict regional coordinate systems for evaluating changes in contour migration and

volume changes. Several common start/ending points for CLARIS surveys of different areas/lengths are labeled. DEM based on 2014 NOAA Post-Sandy topobathymetric lidar collected by NOAA National Geodetic Survey Remote Sensing Division using a RiegI VQ820G

system, acquired from 201311- 201406. Spatial References Vertical - North American Vertical Datum of 1988. Horizontal- NAD 1983 State Plane Coordinate System, Zone 3200.

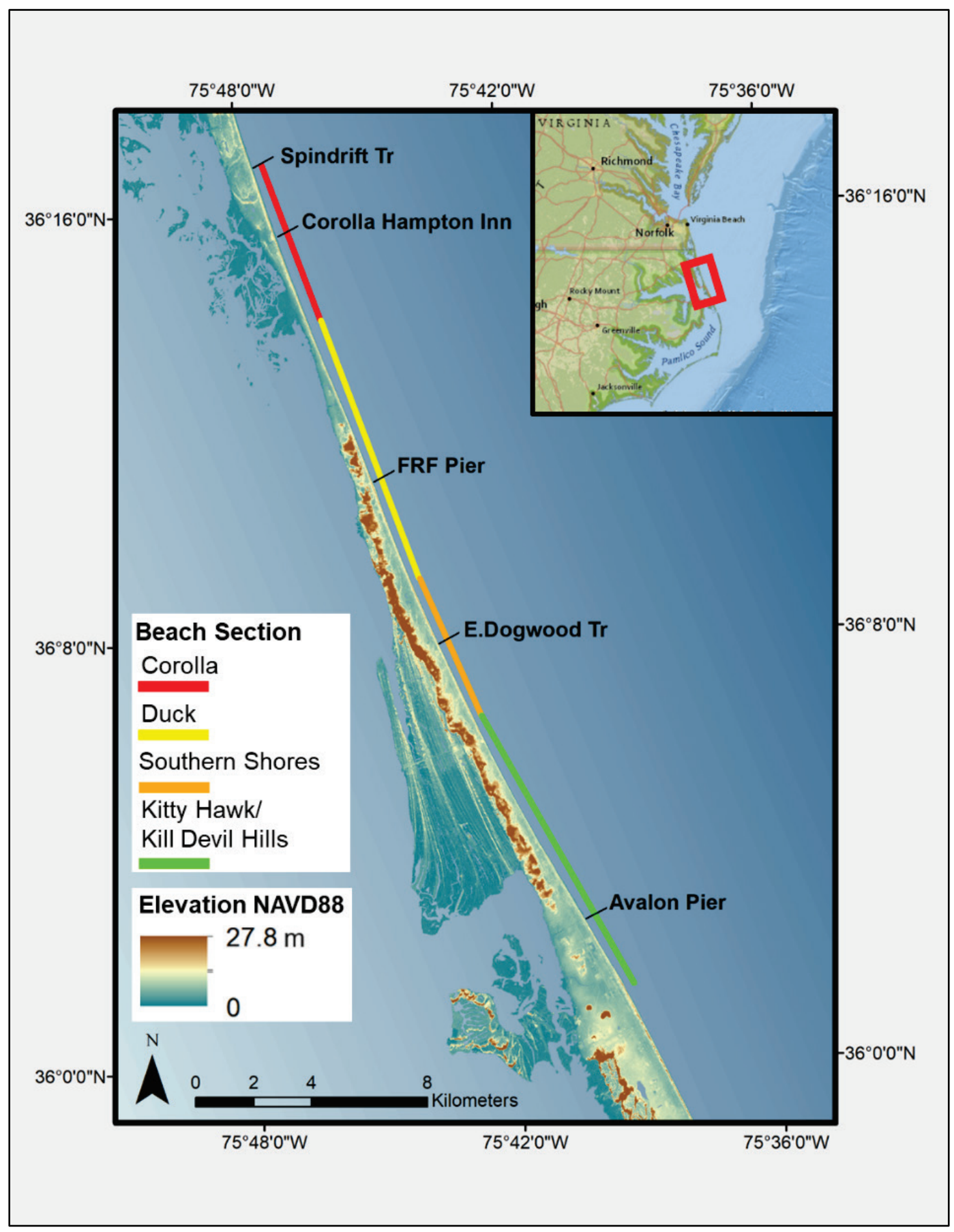


Figure 2-5. CLARIS coverage alongshore (horizontal axis) through time (vertical axis), including named storms impacting the Outer Banks and unnamed storm events (mainly nor'easters) that had significant wave heights over $3 \mathrm{~m}$ (as measured at the FRF $17 \mathrm{~m}$ Waverider buoy) lasting over 8 hours. Spindrift Trail is in the Pine Island Community in Corolla, NC. The FRF is in Duck, NC. E. Dogwood Trail is in Southern Shores, NC. Avalon Pier is in northern Kill Devil Hills, NC.

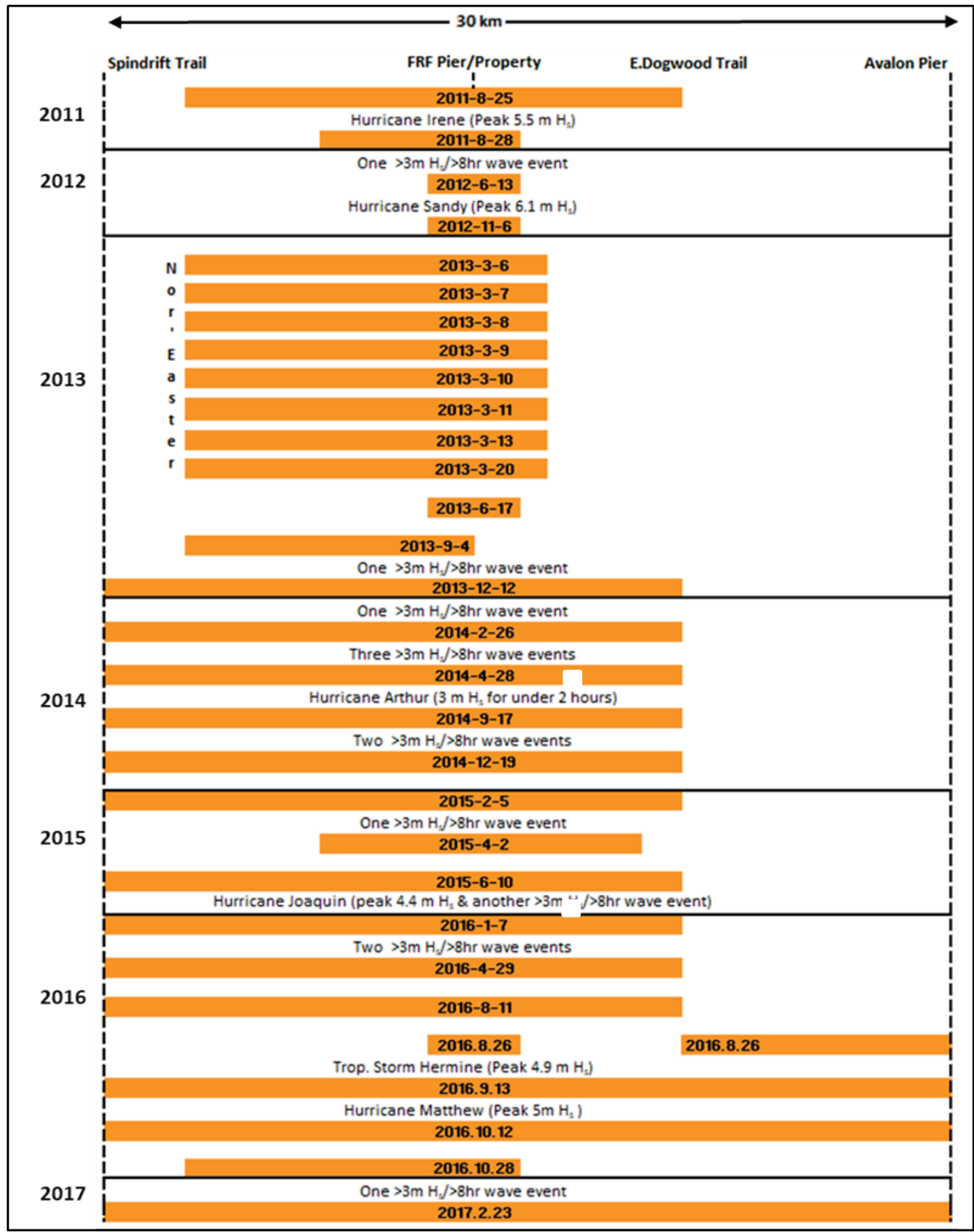




\section{Environmental Conditions}

To facilitate interpretation of the CLARIS data, this chapter documents environmental forcing conditions (wind and wave) and anthropogenic activities that may impact subaerial beach topography for the 2011-2017 study period. The first section presents the bulk statistics of the wave and wind climate; Section 3.2 highlights major events and provides a brief synopsis of each storm.

\subsection{Wave and wind climate}

The northern Outer Banks wave climate is dominated by winter nor'easters as well as passing tropical storms/hurricanes. From August 2011 through February 2017, the mean significant wave height observed at the FRF $17 \mathrm{~m}$ Waverider buoy was $0.96 \mathrm{~m}$ with a minimum value of $0.17 \mathrm{~m}$ and a maximum value of $6.13 \mathrm{~m}$, which was observed during 2012's Hurricane Sandy passing offshore (Figure $3-1$ ). Waves were predominantly from the east, with the $37 \%$ of the records having a southerly component and $45 \%$ with a northerly component (Figure $3-2$ ). Winds on the northern Outer Banks are bimodal with winter and spring winds from the north and summer and fall winds from the south (Figure 3-3). The top sustained winds at the end of the FRF pier were 22.24 meters per second $(\mathrm{m} / \mathrm{s})$, during March 2014.

Figure 3-1. Mean significant wave height $\left(\mathrm{H}_{\mathrm{s}}\right)$ at the $17 \mathrm{~m}$ Waverider buoy with CLARIS surveys noted in dashed vertical lines incrementing through time from blue to red. These colors correspond to the profile evolution figures presented in Chapter 4.

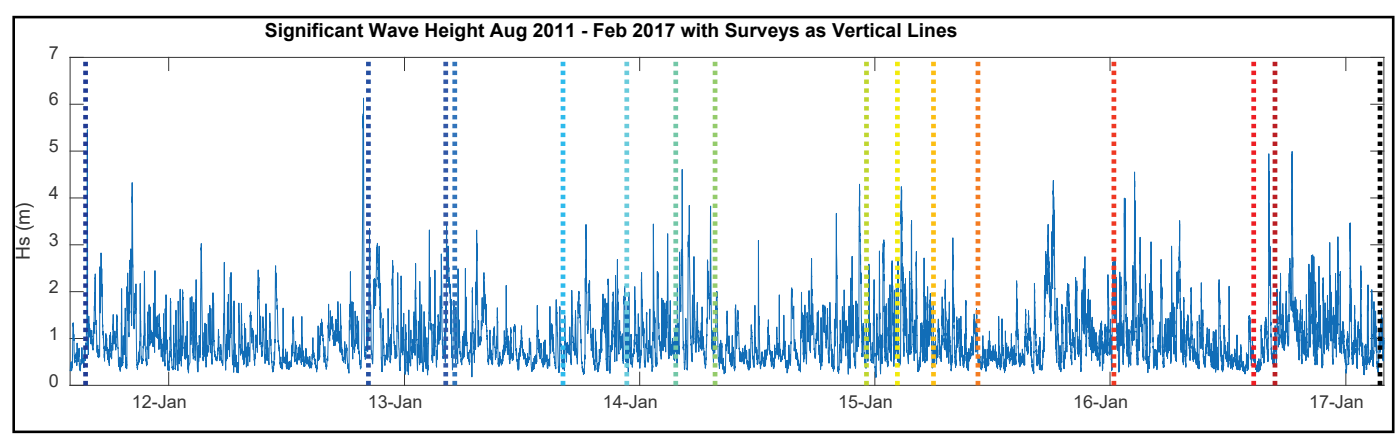


Figure 3-2. Wave rose of significant wave height at the $17 \mathrm{~m}$ Waverider buoy for 2011-2017.

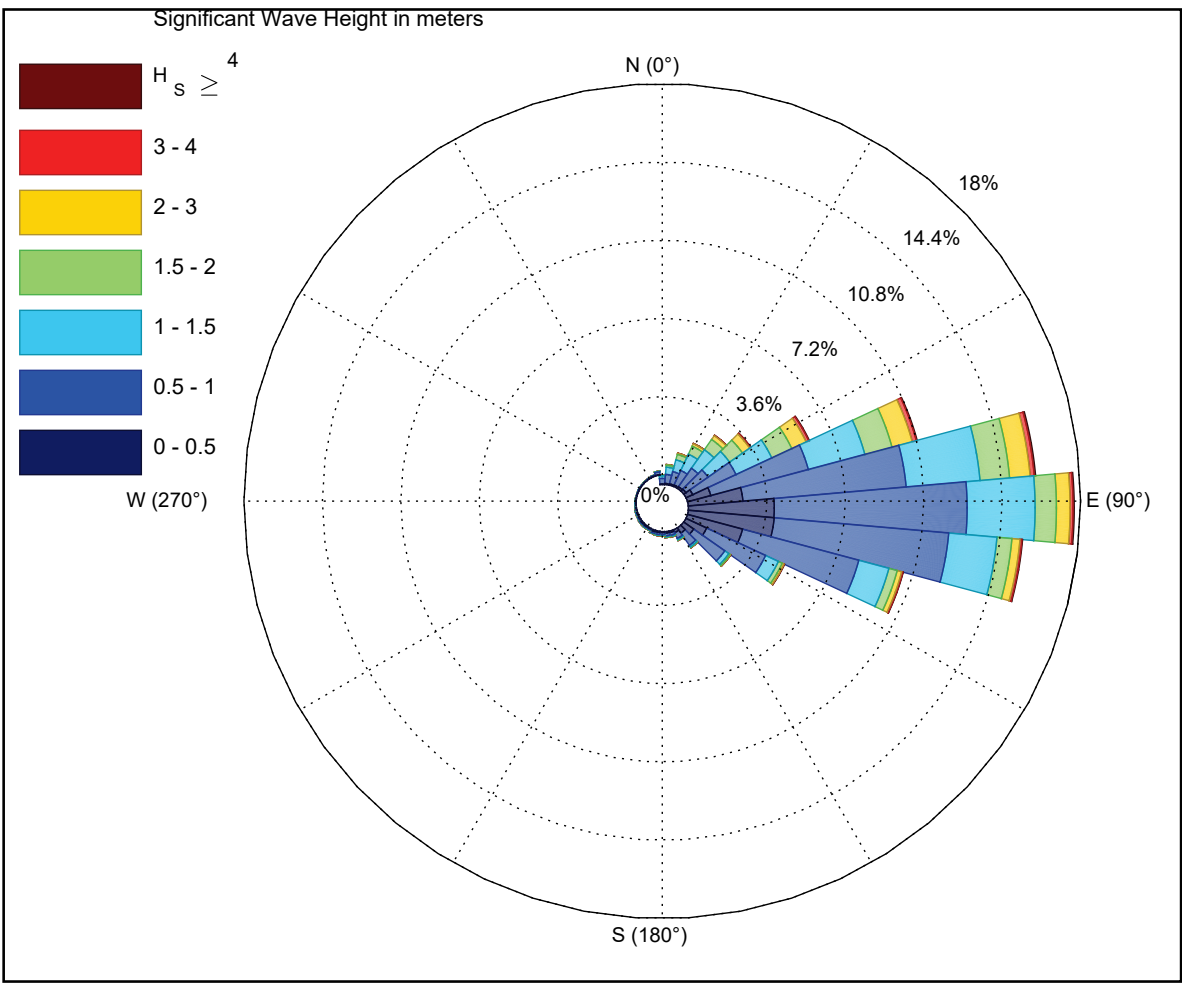

Figure 3-3. Wind rose of winds recorded at the end of FRF pier for 2011-2017.

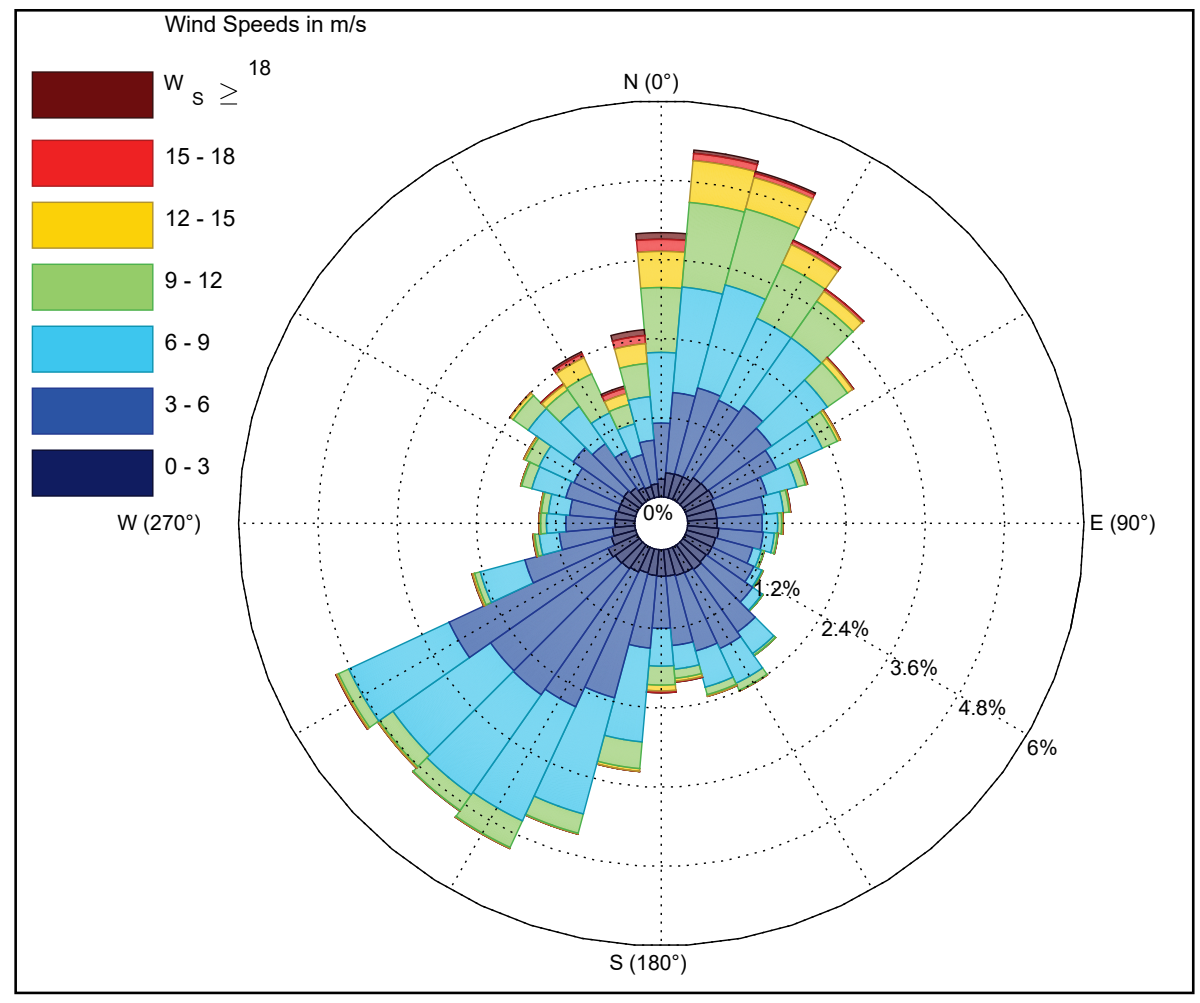




\subsection{Storm events}

The shorelines of the northern Outer Banks are generally most impacted by waves generated during extreme storms, those generated by tropical cyclones in the later summer and fall and nor'easters occurring during the late fall through early spring. Table 3-1 summarizes significant events impacting the region from 2011 to 2017, including six tropical cyclones. The following section describes a selection of significant wave events and pertinent CLARIS surveys to provide context to morphological change analysis.

Table 3-1. Summary of extreme events with significant wave values surpassed $3 \mathrm{~m}$ for more than 8 hours. Values taken from $17 \mathrm{~m}$ Datawell Waverider buoy with any gaps filled in with data from the $11 \mathrm{~m}$ AWAC. *Note: 1/24/2016 is the second peak of that nor'easter. The above period durations only capture the peaks of wave events and in most cases still have significant wave energy remaining on either side of these.

\begin{tabular}{|c|c|c|c|}
\hline \multirow{3}{*}{ Hurricane Irene } & Start Date & $\begin{array}{c}3 \text { m Wave } \\
\text { Duration } \\
\text { (Hrs) }\end{array}$ & $\begin{array}{c}\text { Max } \mathrm{H}_{\mathrm{s}} \\
\text { Value }(\mathrm{m})\end{array}$ \\
\hline & $8 / 27 / 2011$ & 18 & 5.5 \\
\hline & $11 / 4 / 2011$ & 28 & 4.3 \\
\hline \multirow[t]{11}{*}{ Hurricane Sandy } & $10 / 27 / 2012$ & 53 & 6.1 \\
\hline & $3 / 7 / 2013$ & 14 & 3.5 \\
\hline & $10 / 9 / 2013$ & 16 & 3.4 \\
\hline & $1 / 22 / 2014$ & 9 & 3.4 \\
\hline & $3 / 6 / 2014$ & 21 & 4.6 \\
\hline & $3 / 18 / 2014$ & 15 & 3.8 \\
\hline & $4 / 20 / 2014$ & 15 & 3.8 \\
\hline & $11 / 2 / 2014$ & 11 & 3.7 \\
\hline & $12 / 7 / 2014$ & 44 & 4.3 \\
\hline & $2 / 10 / 2015$ & 35 & 4.2 \\
\hline & $9 / 26 / 2015$ & 9 & 3.4 \\
\hline \multirow[t]{4}{*}{ Hurricane Joaquin } & $10 / 2 / 2015$ & 61 & 4.4 \\
\hline & $1 / 23 / 2016$ & 8 & 4.0 \\
\hline & $1 / 24 / 2016^{*}$ & 15 & 4.0 \\
\hline & $2 / 7 / 2016$ & 35 & 4.6 \\
\hline \multirow{3}{*}{$\begin{array}{l}\text { Trop.Storm Hermine } \\
\text { Hurricane Matthew }\end{array}$} & $9 / 3 / 2016$ & 24 & 4.9 \\
\hline & $10 / 9 / 2016$ & 32 & 5.0 \\
\hline & $1 / 7 / 2017$ & 14 & 3.5 \\
\hline
\end{tabular}




\subsubsection{1: Hurricane Irene}

Hurricane Irene directly impacted the northern Outer Banks, with the eye approaching from the southwest across the sounds and passing approximately $5 \mathrm{~km}$ north of the FRF property as a Category 1 storm on 27 August 2011. A CLARIS survey captured the pre-storm conditions on 26 August 2011 ( $~ 30$ hours before the storm's landfall) from Pine Island down to Southern Shores, NC. The post-storm survey assessed conditions on 28 August 2011, 1 day after the hurricane's passage, from the southern FRF property line north to the Sanderling Resort in northern Duck, NC.

Winds peaked at 75 knots at the end of the FRF pier, and significant wave height peaked at $5.5 \mathrm{~m}$ at the $17 \mathrm{~m}$ wave buoy (Figure $3-4$ ). As detailed in McNinch et al. (2012), wave setup and runup accounted for $78 \%$ of the $4.26 \mathrm{~m}$ maximum water level observed at the FRF ocean shoreline, with tide and storm surge accounting for $0.37 \mathrm{~m}$ and $0.55 \mathrm{~m}$, respectively. While there were erosional hotspots to the north of the FRF pier (approximately $3 \mathrm{~km}$ north in Duck, NC, and within the embayment just to the north of the pier), overall erosion was limited near the FRF, with volume loss equating to less than 10 centimeters $(\mathrm{cm})$ in the vertical across $7 \mathrm{~km}$ of surveyed beach (McNinch et al. 2012). Dune toe erosion also was primarily limited to shoreline embayments north of the FRF pier. These areas correlated with the existence of minimal sandbars. Given the hurricane's approach, the sound-side of the northern Outer Banks saw the majority of the impacts, experiencing historic flooding driven by storm surge and seiching in the Currituck Sound and greater Albemarle-Pamlico estuary system.

Figure 3-4. Significant wave height $\left(\mathrm{H}_{\mathrm{s}}\right)$ in meters (blue) and wave period during Hurricane Irene.

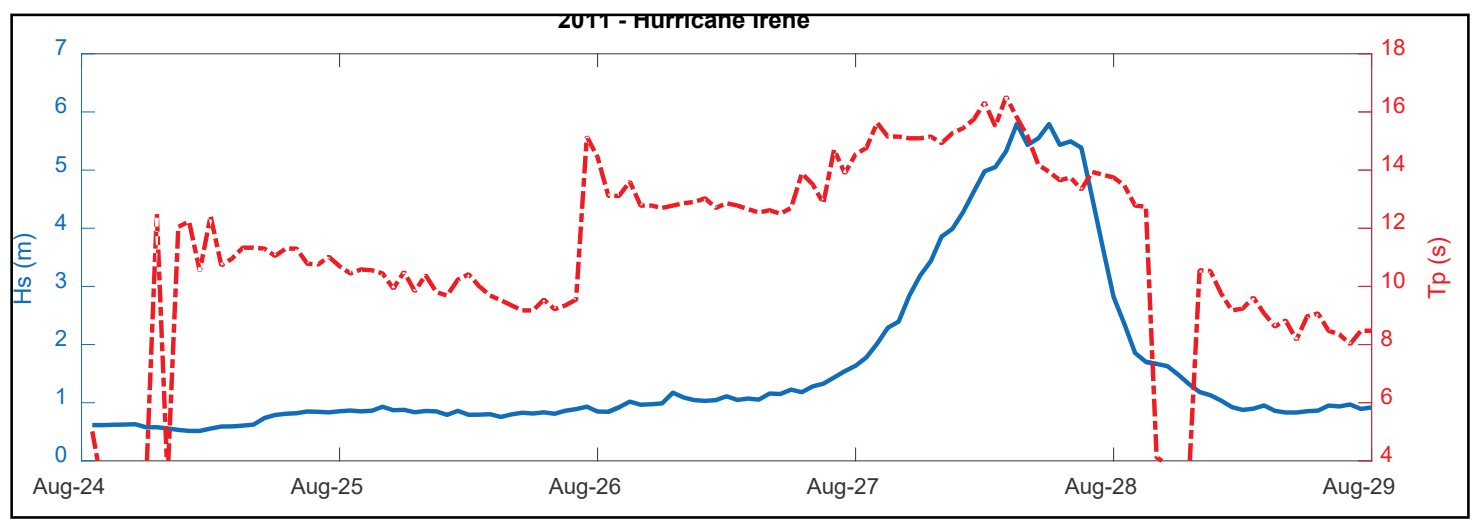




\subsubsection{2: Hurricane Sandy}

Late in October of 2012, Hurricane Sandy passed within $500 \mathrm{~km}$ offshore of the northern Outer Banks as Category 1 hurricane, generating over $1.2 \mathrm{~m}$ of storm surge before heading north and turning in to New Jersey (Blake et al. 2013). Winds at the FRF pier peaked at over $25 \mathrm{~m} / \mathrm{s}$, and significant wave heights were over $6 \mathrm{~m}$ at the $17 \mathrm{~m}$ Waverider buoy (Figure 3-5). The dunes on the FRF property and surrounding area saw significant retreat during the storm due to extended periods of wave runup (Brodie and Spore 2015). After the storm, a number of property owners in this area performed beach scrapes and brought in additional sand to rebuild their dunes before winter (Brodie and Spore 2015).

The most recent pre-storm CLARIS survey available was on 13 June 2012 and was focused on the FRF property's shoreline. The post-storm survey was collected immediately after the storm on 6 November 2012 also focused on the FRF property.

Figure 3-5. Significant wave height $\left(H_{s}\right)$ in meters (blue) and wave period during Hurricane Sandy.

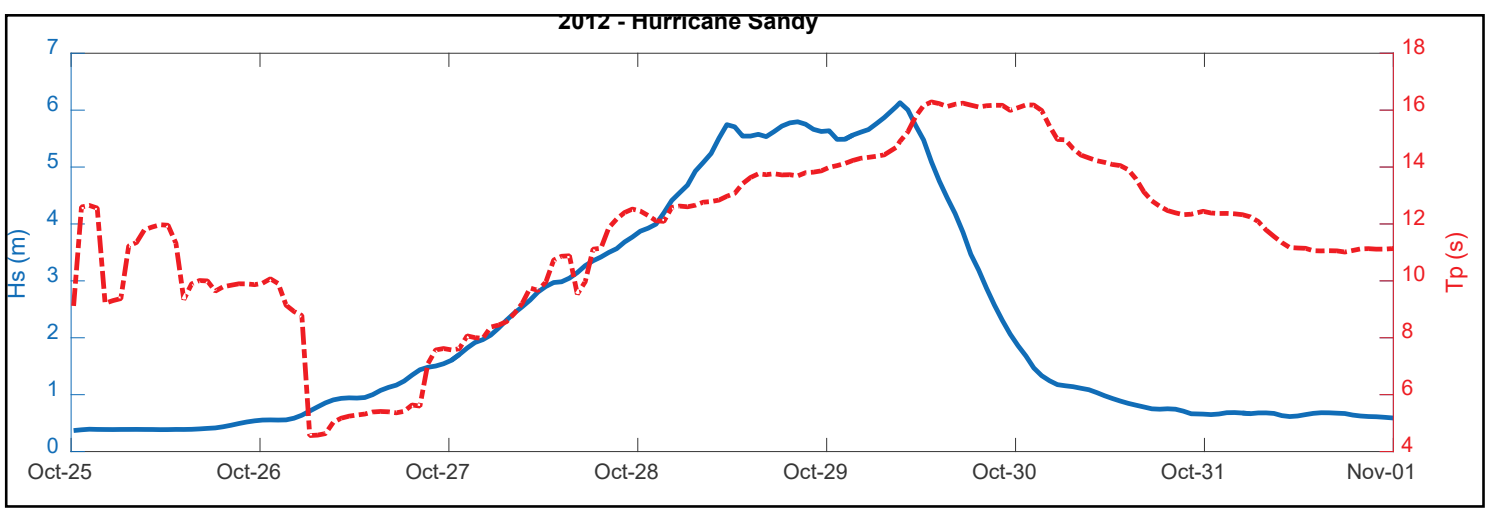

\subsubsection{3: March 2013 nor'easter}

On 6 March 2013, a nor'easter generated waves with $\mathrm{Hs}>3 \mathrm{~m}$ for more than 4 days at the FRF $8 \mathrm{~m}$ array (14 consecutive hours over $3 \mathrm{~m}$ at the $17 \mathrm{~m}$ Waverider Buoy). In $17 \mathrm{~m}$ water depth waves peaked at $3.5 \mathrm{~m}$ and predominantly originated from the north/northeast (Figure 3-6), as illustrated in Brodie and Spore (2015) and Figure 3-5. CLARIS was deployed several times during this nor'easter, collected daily from 6-11 March 2013 as well as March 13 and soon after on March 20. These surveys all covered $12 \mathrm{~km}$ from Pine Island in the north to slightly south of the FRF at Schooner Ridge Dr. in Duck, NC. The March 6 survey captured 
the beach condition prior to the peak of the storm, as shown in Figure 3-6. The nearest in time CLARIS survey prior to the March 2013 surveys was 6 November 2012 and was constrained to the FRF property.

This storm generated the first significant dune collision event since Hurricane Sandy. The study by Brodie and Spore (2015) using CLARIS data collected during this storm documents high dune erosion along the $2 \mathrm{~km}$ of beach immediately north of the FRF property. The erosion was especially evident in areas where manmade dunes had been constructed following Hurricane Sandy (average erosion of $\sim 1.15 \mathrm{~m} /$ day while dunes that were scarped prior to the nor'easter saw erosion rates of $0.69 \mathrm{~m} /$ day).

Figure 3-6. Significant wave height $\left(H_{s}\right)$ in meters (blue) and wave period during a 2013 March nor'easter.

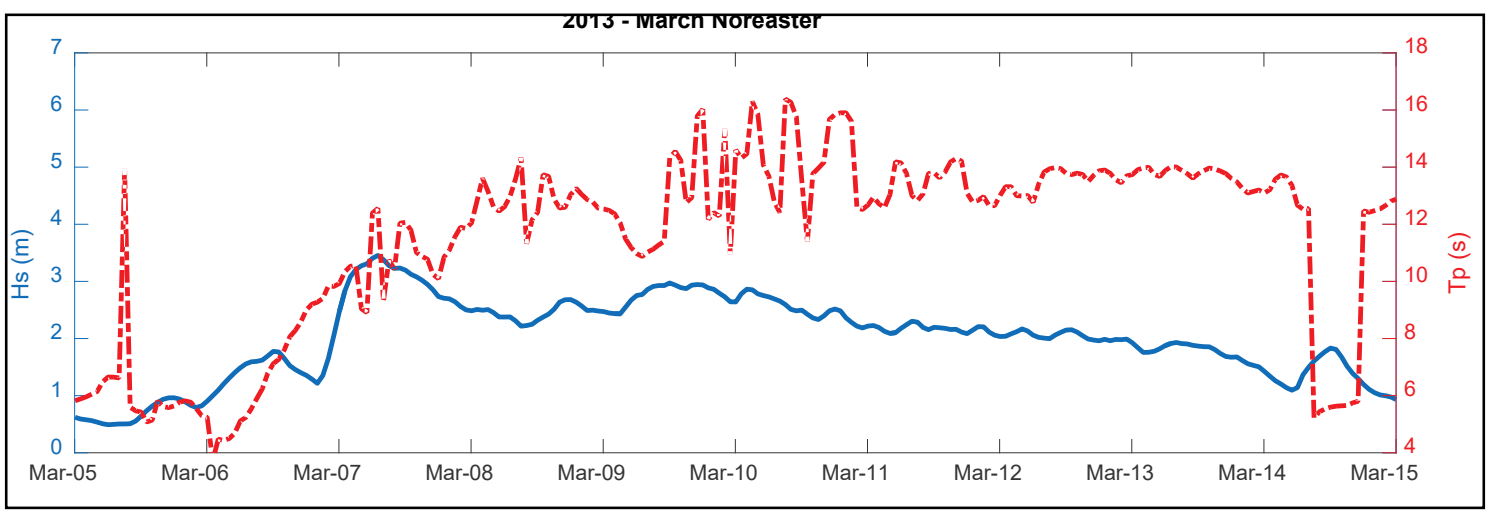

\subsubsection{4: Hurricane Arthur}

At the beginning of July 2014, Hurricane Arthur became the earliest-season hurricane to make landfall in North Carolina since records began in 1851 (Berg 2015). The storm made landfall just east of Beaufort, NC, at Shackleford Banks before passing over the Outer Banks just north of Oregon Inlet. Despite the path, damage within the survey area was limited, with the majority of flooding and overwash occurring south of Oregon Inlet. At the FRF, winds approached $25 \mathrm{~m} / \mathrm{s}$, and significant wave height peaked over $3.5 \mathrm{~m}$ but only remained over $3 \mathrm{~m}$ for under 4 hours (Figure $3-7$ ).

The closest survey data available prior to the passage of Hurricane Arthur were from 28 April 2014 covering from Spindrift Trail in the Currituck County Pine Island community down to E. Dogwood Trail in Southern Shores, NC. The same stretch of beach was covered on September 17 of the same year. Note: CLARIS surveys were attempted 
immediately before and after the storm, but the lidar scanner malfunctioned, returning unusable data.

Figure 3-7. Significant wave height $\left(H_{s}\right)$ in meters (blue) and wave period during Hurricane Arthur.

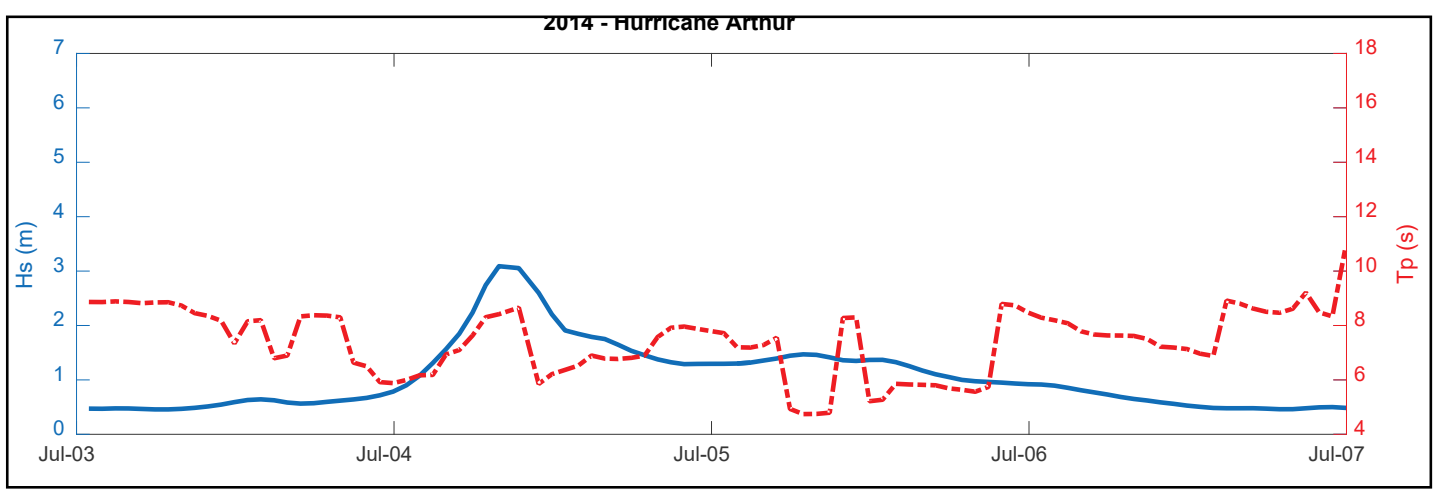

\subsubsection{5: Hurricane Joaquin/nor'easter (early Oct 2015)}

Hurricane Joaquin was a major Category 4 Hurricane that stayed offshore after its intensification over the Bahamas in late September 2015. As the hurricane moved northeastward, a pressure gradient off New England forced a number of nor'easters nearby the northern Outer Banks while upper-level moisture from Hurricane Joaquin was also drawn towards the coast (Berg 2016). The hurricane swell and nor'easter waves combined with high tides causing damaging surge and waves along the Outer Banks. Significant wave heights were over $3 \mathrm{~m}$ for more than 4 days (peaking at $4.4 \mathrm{~m}$ ) with winds above $16 \mathrm{~m} / \mathrm{s}$ (Figure 3-8). At the FRF, these coastal conditions led to wave runup impacting the dune toe in certain locations for five high tides, resulting in up to $8 \mathrm{~m}$ of dune toe erosion on the northern side of the property (Brodie et al. 2018b).

A CLARIS survey on 10 June 2015 was the most recent survey prior to Hurricane Joaquin's passage. The closest CLARIS survey following the storm was on 7 January 2016. Both surveys covered the Corolla, Duck, and half the Southern Shores beach survey sections. While there were sustained waves at the end of September prior to the storm, no events with sustained ( $>8$ hours) waves over $3 \mathrm{~m}$ occurred between the storm and the January beach survey (Table 3-1). 
Figure 3-8. Significant wave height (Hs) in meters (blue) and wave period during Hurricane Joaquin/nor'easter.

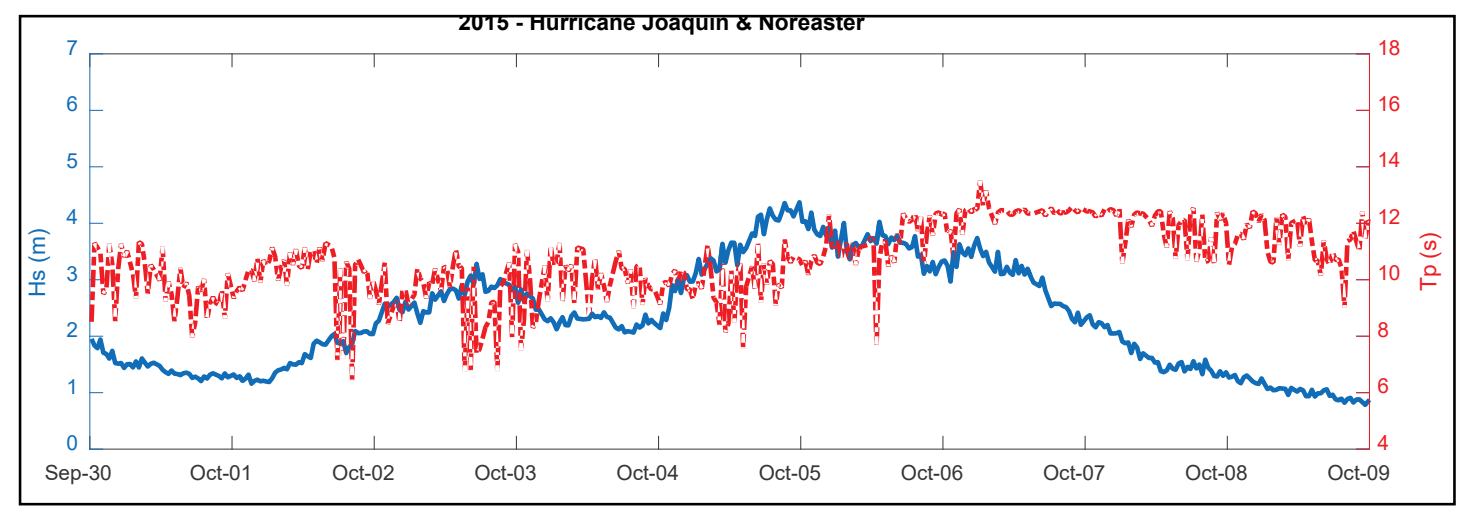

\subsubsection{6: Winter 2016 nor'easters}

Nor'easters early in 2016 ( January 23, also referenced to by The Weather Channel as Jonas, and February 8, aka Mars) generated extended periods of high wave energy along the northern Outer Banks. Significant wave height peaked at approximately 4 and $4.6 \mathrm{~m}$ with winds over 15 and $21.6 \mathrm{~m} / \mathrm{s}$, respectively (Figure 3-9 and Figure 3-10). The late January storm produced a small amount of snow.

The January 23 and February 8 nor'easters were the two largest of the five nor'easters that passed between CLARIS surveys conducted on 7 January 2016 and 29 April 2016. The data cover the $20 \mathrm{~km}$ of beach between Spindrift Trail in Pine Island and E. Dogwood Trail in Southern Shores. During the January nor'easter there was limited dune scarping within the northern half of the FRF property, though the overall beach elevation remained relatively stable. Overwash was reported on the Outer Banks during these storms (in the towns of Kitty Hawk and Buxton), but these areas were south of the survey area.

Figure 3-9. Significant wave height $\left(H_{s}\right)$ in meters (blue) and wave period during a January 2016 nor'easter.

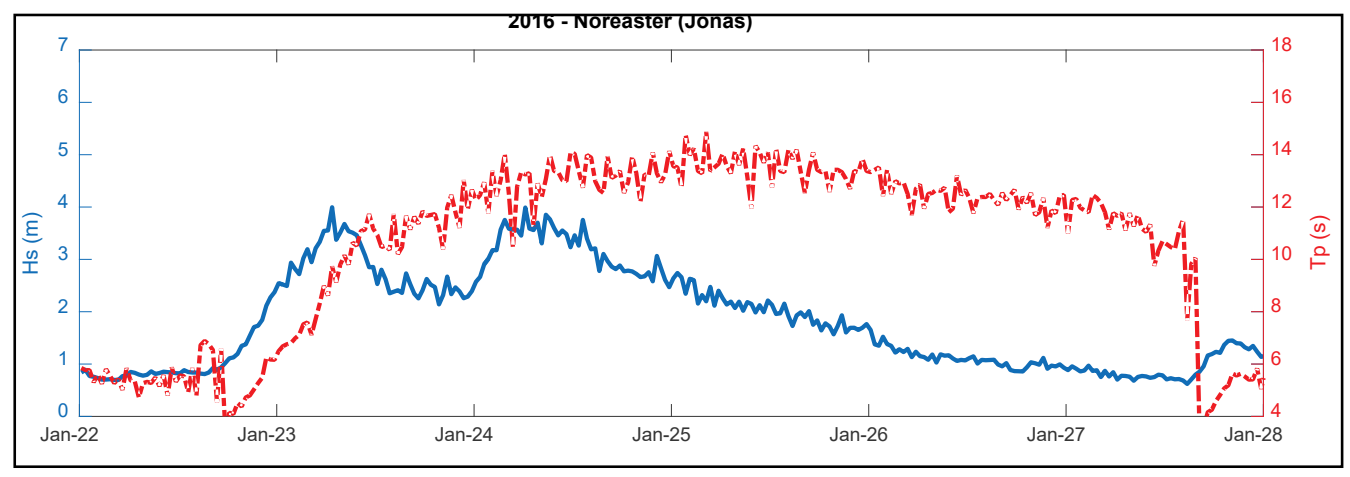


Figure 3-10. Significant wave height $\left(H_{s}\right)$ in meters (blue) and wave period during a February nor'easter

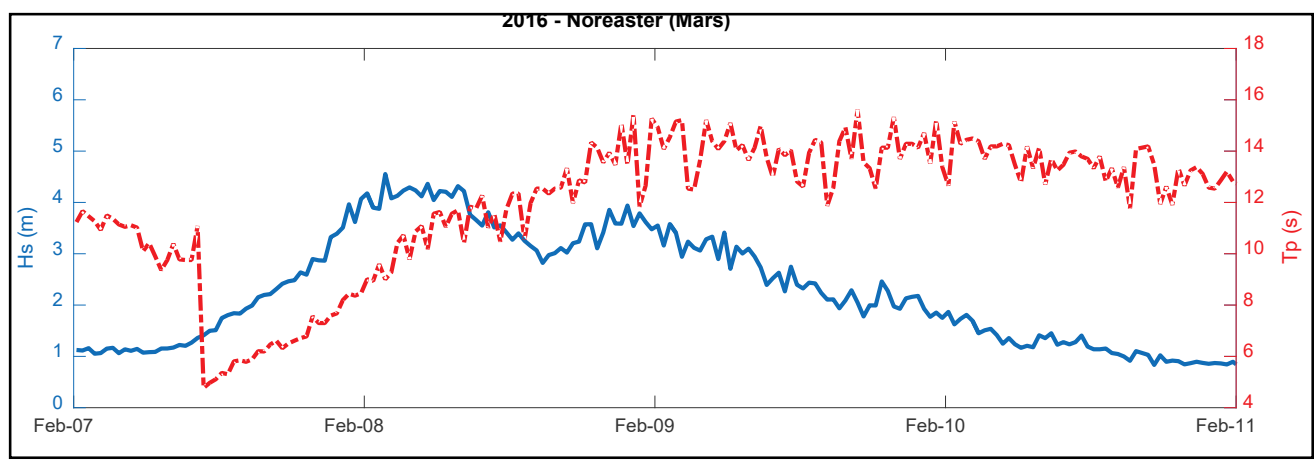

\subsubsection{Tropical Storm Hermine}

Tropical Storm Hermine (September 2016) caused significant coastal flooding to the south along the Outer Banks (particularly in Frisco, NC); however, the storm did not lead to major overwash within the CLARIS survey area. At the FRF, there was some dune erosion along the northern half of the property while dunes along the southern half of the property remained relatively stable. The dune erosion was particularly evident in the $0.2 \mathrm{~km}$ north of the FRF pier, with up to $5 \mathrm{~m}$ of erosion in this area (Brodie et al. 2018b). Significant wave height peaked at $4.9 \mathrm{~m}$ with winds at $29.2 \mathrm{~m} / \mathrm{s}$ (Figure $3-11$ ).

Following Hurricane Hermine, the entire $30 \mathrm{~km}$ between Pine Island and Kill Devil Hills, NC (to Avalon Pier), was surveyed with CLARIS. Two weeks prior to Hermine on 26 August 2016, a CLARIS survey of the FRF property as well as sections of the beach from Southern Shores through Kitty Hawk and into Kill Devil Kills, NC, was also collected. On 11 August 2018, CLARIS surveys was also conducted in Corolla, Duck and Southern Shores, NC.

Figure 3-11. Significant wave height $\left(H_{s}\right)$ in meters (blue) and wave period during Tropical Storm Hermine.

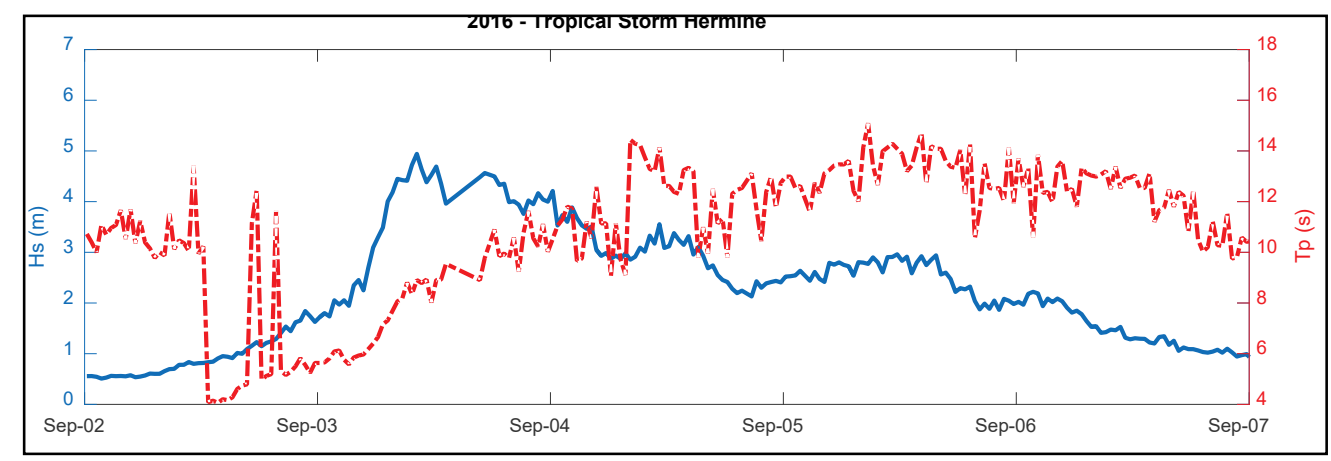




\subsubsection{Hurricane Matthew}

Hurricane Matthew made landfall in South Carolina before continuing up the coast with sustained hurricane-force wind and historic levels of precipitation as it remained just offshore of the Carolinas before merging with a front system east of Cape Hatteras and heading farther out to sea (Stewart 2017). At the FRF there was significant erosion - particularly of the beach and dune along the northern $0.25 \mathrm{~km}$ of the property as well as the dune toe immediately along the FRF pier (up to $3 \mathrm{~m}$ of erosion; Brodie et al. 2018b). Farther south along highway NC12 in Kitty Hawk, waves overtopped the dune causing overwash and significant damage to dunes and the pavement (Stewart 2017). NC12 was breached just north of previously placed sandbags. Overwash combined with significant precipitation and sound-side flooding resulting in areas of standing water behind the dune line. Storm surge at the FRF pier was measured at $1.0 \mathrm{~m}$, with significant wave heights up to $5 \mathrm{~m}$ and winds over $32.3 \mathrm{~m} / \mathrm{s}$ (Figure $3-12$ ).

CLARIS data were last collected prior to Hurricane Matthew on 13 September 2016 and after the storm on 12 October 2016, over $30 \mathrm{~km}$ of shoreline between Pine Island to the north and Avalon Pier to the south (within the Kitty Hawk/Kill Devil Hills segment of northern Outer Banks surveyed beach).

Figure 3-12. Significant wave height $\left(H_{s}\right)$ in meters (blue) and wave period during Hurricane Matthew.

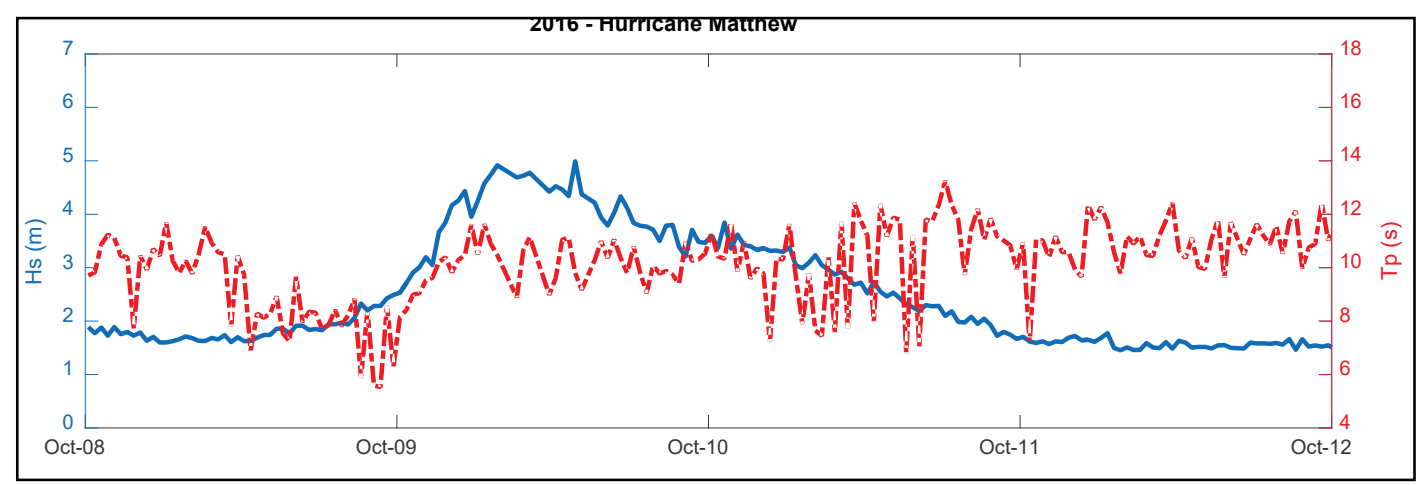




\title{
4 Coastal Lidar and Radar Imaging System (CLARIS) Data
}

\author{
A summary of the CLARIS data collected from August 2011 to January \\ 2017 is presented in the following chapter. The first section will detail how \\ each metric or statistic was calculated, and the following sections will \\ describe results from each sub-region within survey extents.
}

\subsection{Parametric and statistic calculations}

After the ground-classified DEMs were created, statistics were generated across the spatial and temporal domains of the data. These calculations require physical parameters to be extracted from each DEM, namely dune crest, dune toe, and shoreline. The dune crest ( $\left.\mathrm{D}_{\text {hi }}\right)$ was defined as the maximum elevation along each $2 \mathrm{~m}$ wide cross-shore transect and its associated cross-shore position. The dune toe (Dlo) was defined at the $3 \mathrm{~m}$ elevation contour and its associated cross-shore position. The shoreline was defined at the $1 \mathrm{~m}$ elevation contour and its associated cross-shore position. The $1 \mathrm{~m}$ contour was chosen due to data availability, as the $\mathrm{o} \mathrm{m}$ contour was not always measureable during a survey due to runup.

Foredune face volume was defined at each $2 \mathrm{~m}$ cross-shore transect as the area under the profile between $D_{\text {hi }}$ and $D_{\text {lo }}$ multiplied by the along-shore cell size $(2 \mathrm{~m})$. Beach volume was defined at each $2 \mathrm{~m}$ cross-shore transect as the area under the curve between Dlo and the shoreline multiplied by the along-shore cell size $(2 \mathrm{~m})$. Beach slope was defined as the slope of the best fit linear trend between the Dlo position and shoreline position.

The physical parameters at each along-shore transect can be represented as discrete data points through time. A linear model was fit to the physical parameter of interest through time at each along-shore transect, and the slope of each model represented the linear trend at each transect. Trends that coincided with p-values greater than 0.05 were considered not significantly correlated and were omitted from this report's analysis. Plots for annual dune volume change and shoreline cross-shore position change resulted, and the transect trend values were colored by the value of the coefficient of determination $\left(\mathrm{R}^{2}\right)$.

Cumulative elevation change was calculated at each grid cell as the sum of all elevation change values over the 6-year period. Two representative 
profiles were also extracted to highlight areas within the region that experienced significant change. Average dune volume, beach volume, and beach slope were computed for all transects within each region.

\subsubsection{Region 1: Corolla}

The Corolla region is characterized by an along-shore embayment and exhibits a generally accretive trend throughout the 2011-2017 study period. The shoreline north of the embayment's apex has accreted seaward up to $5 \mathrm{~m}$ per year in some locations, and dune volume has also been increasing in this area (Figure 4-1).

Figure 4-1. (left) Linear fit of dune volume change per year at each along-shore transect colored by the coefficient of determination $\left(R^{2}\right)$. Points that are grey colored had $p$-values greater than 0.05; (center) Average dune crest ( $\mathrm{Dhi}_{\mathrm{hi}}$ ), dune toe ( $\mathrm{D}_{\mathrm{lo}} 3 \mathrm{~m}$ contour), and shoreline (shore $1 \mathrm{~m}$ contour) cross-shore position with $+/$ - one standard deviation shaded; legend at the bottom corresponds to the center panel; (right) Linear fit of shoreline cross-shore position change per year at each alongshore transect color by the coefficient of determination $\left(R^{2}\right)$. All panels correspond to the Corolla beach segment data of the northern Outer Banks surveyed by CLARIS.

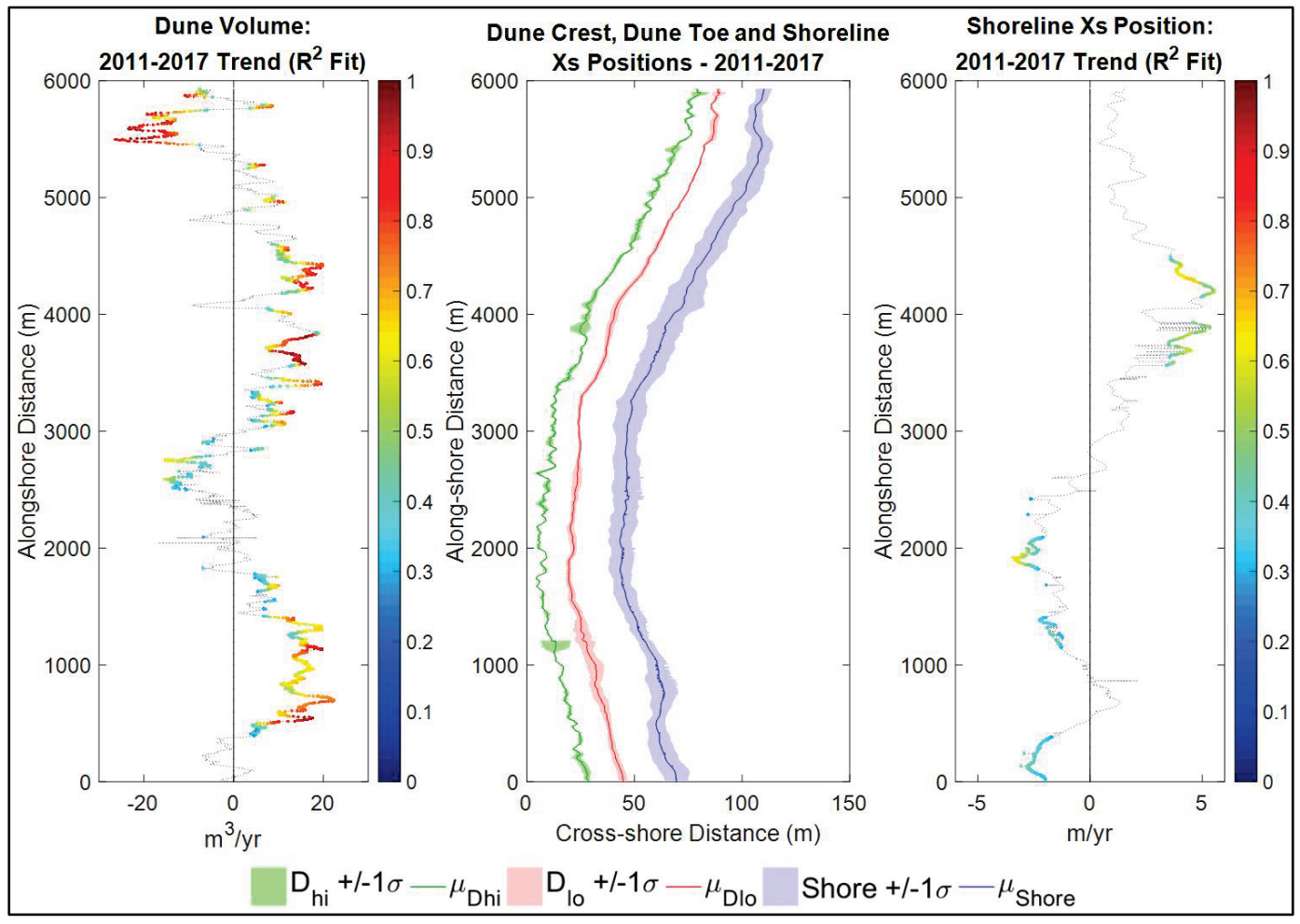

Figure 4-2 shows the alongshore variability of elevation change, particularly near the dune. The foredune is prograding along most of the region during the study period (example Profile A) aside from two hot spots at approximately $\mathrm{y}=2700 \mathrm{~m}$ and $\mathrm{y}=5800 \mathrm{~m}$ (Profile $\mathrm{B}$ ). Along-shore- 
averaged transect dune volume has fluctuated between 60 and $80 \mathrm{~m} 3 / \mathrm{m}$ and along-shore-averaged transect beach volume was bounded between 35 and $55 \mathrm{~m} 3 / \mathrm{m}$ (Figure 4-3). Along-shore-average beach slope oscillated between -0.05 and $-0.03 \mathrm{~m} / \mathrm{m}$ (Figure 4-4) and was the flattest region amongst the three regions of the 2011-2017 study period.

Figure 4-2. Cumulative elevation change along the Corolla beach segment of the northern Outer Banks between 2011 and 2017.

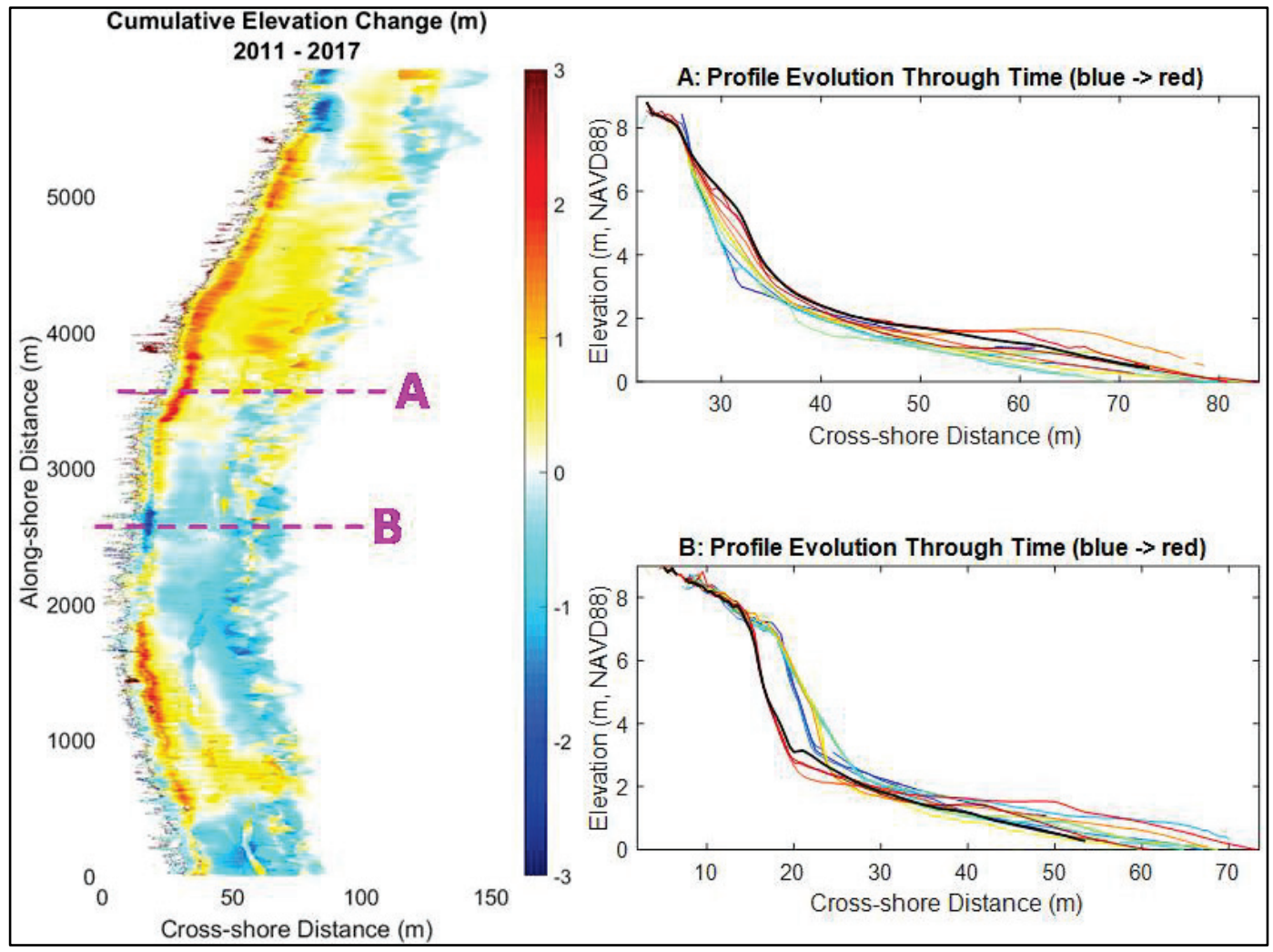


Figure 4-3. Average dune and beach volume for transects within the Corolla beach segment. Dune volume was defined at each $2 \mathrm{~m}$ cross-shore transect as the area under the curve between dune crest and the $3 \mathrm{~m}$ contour. Beach volume defined as volume between the shoreline ( $1 \mathrm{~m}$ contour) and dune toe ( $3 \mathrm{~m}$ contour) for each $2 \mathrm{~m}$ wide transect.

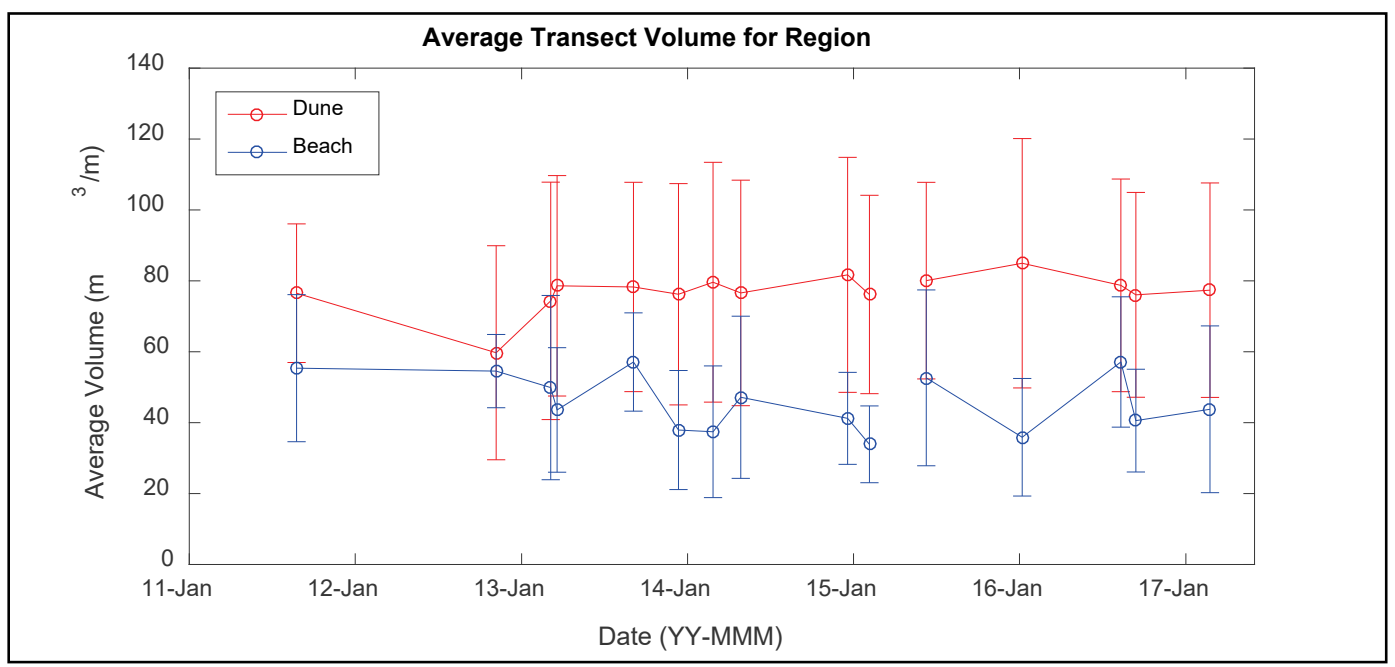

Figure 4-4. Average dune and beach slope for transects within the Corolla beach survey segment Beach slope was calculated between the dune tow $\left(D_{10}\right)$ defined at the $3 \mathrm{~m}$ contour and the shoreline, defined at the $1 \mathrm{~m}$ contour.

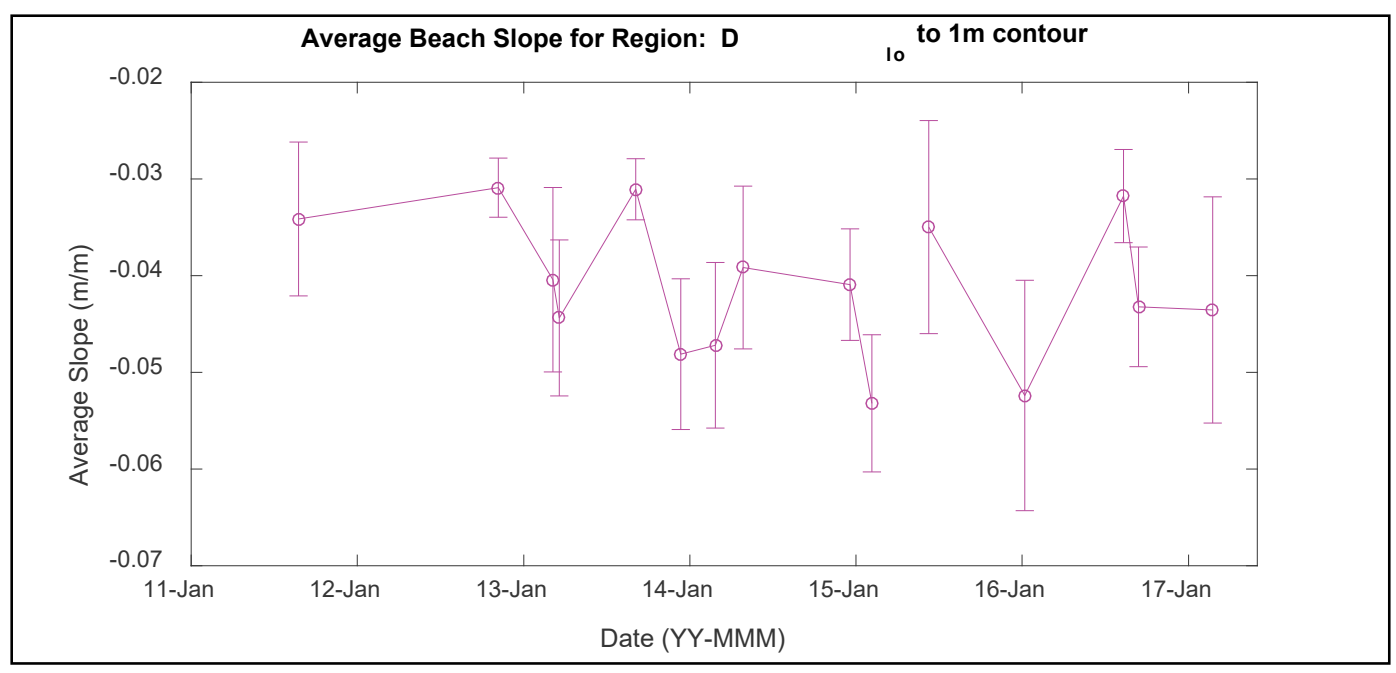

\subsubsection{Region 2: Duck}

The Duck region is adjacent to and south of the Corolla region and is characterized by an alongshore promontory that peaks near the FRF research pier, near $\mathrm{y}=4000 \mathrm{~m}$. The dune volume trend was mostly accretive during the study period with $10-20 \mathrm{~m}^{3} /$ year of gains at the northern end of the promontory (Figure 4-5). To the south, the opposite occurred with frequent dune collision and erosion, noted by the narrowness of the dune between $\mathrm{y}=4000 \mathrm{~m}$ and $\mathrm{y}=6000 \mathrm{~m}$ along-shore. 
The shoreline observations suggested retreat throughout the region with some areas experiencing 2-3 m/year losses.

Figure 4-5. (left) Linear fit of dune volume change per year at each alongshore transect colored by the coefficient of determination $\left(R^{2}\right)$; (center) Average dune crest $\left(D_{h i}\right)$, dune toe

( $D_{10} 3 \mathrm{~m}$ contour), and shoreline (shore $1 \mathrm{~m}$ contour) cross-shore position with +/- one standard deviation shaded; legend at the bottom corresponds to the center panel; (right) Linear fit of shoreline cross-shore position change per year at each alongshore transect color by the coefficient of determination $\left(R^{2}\right)$. All panels correspond to the Duck beach segment data of the northern Outer Banks surveyed by CLARIS.

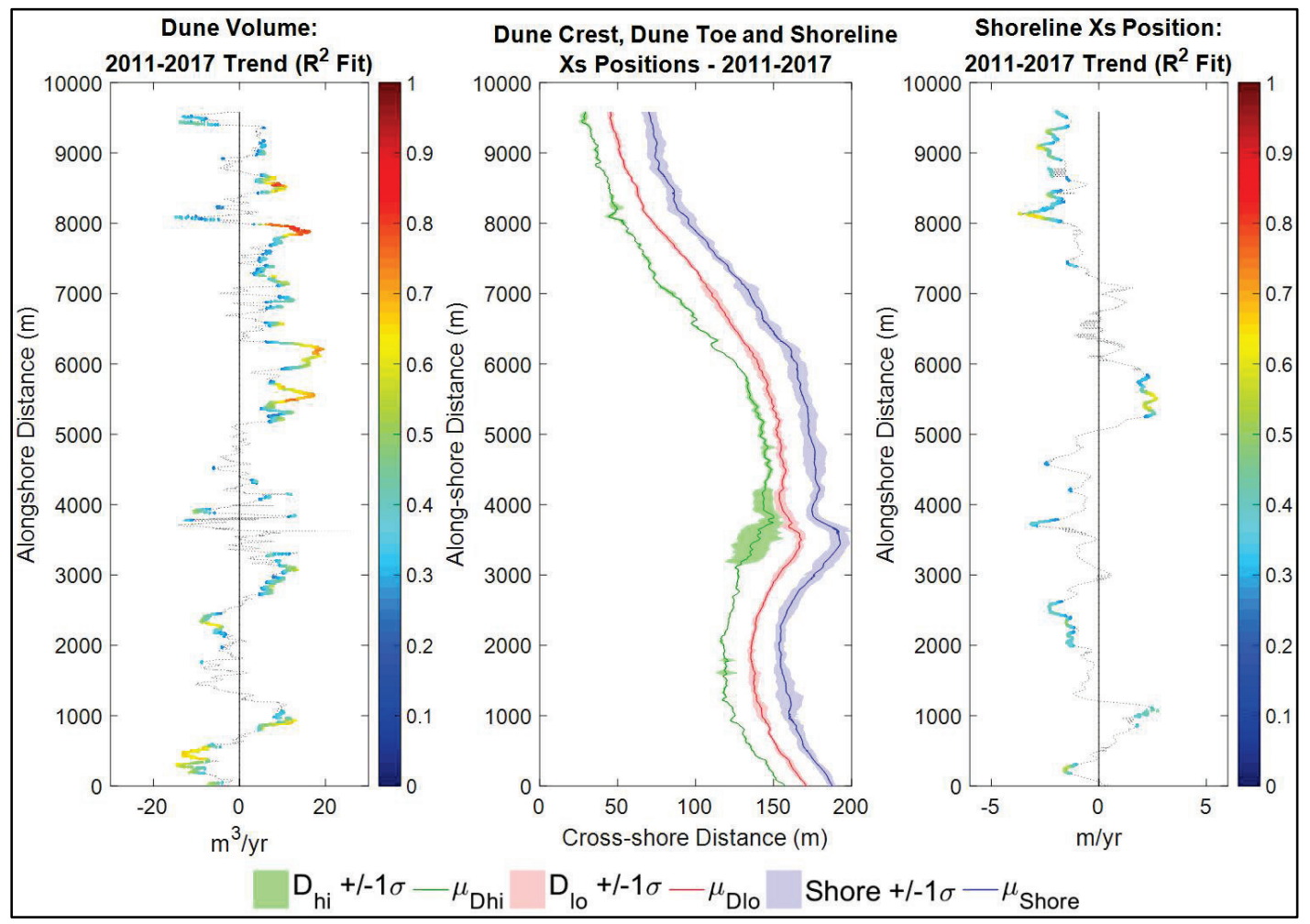

An erosional hotspot was present near the apex of the promontory between $\mathrm{y}=4500 \mathrm{~m}$ and $\mathrm{y}=5500 \mathrm{~m}$ alongshore. Elevation losses greater than $3 \mathrm{~m}$ occurred during the study period on the upper beach and foredune face within this area. The dune volume trends (Figure 4-6) in this region did not reflect the losses observed in the cumulative elevation change (Figure 4-6), primarily due to beach scraping activities in this area by concerned homeowners (Profile B, Figure 4-6). Areas north of the promontory experienced a prograding foredune (Profile A, Figure 4-6), which accreted approximately $1 \mathrm{~m}$ vertically and $5 \mathrm{~m}$ laterally. 
Figure 4-6. Cumulative elevation change along the Duck beach segment of the northern Outer Banks between 2011 and 2017. For reference, the FRF pier is located at $3700 \mathrm{~m}$ along-shore within the regional Duck beach segment coordinate system.

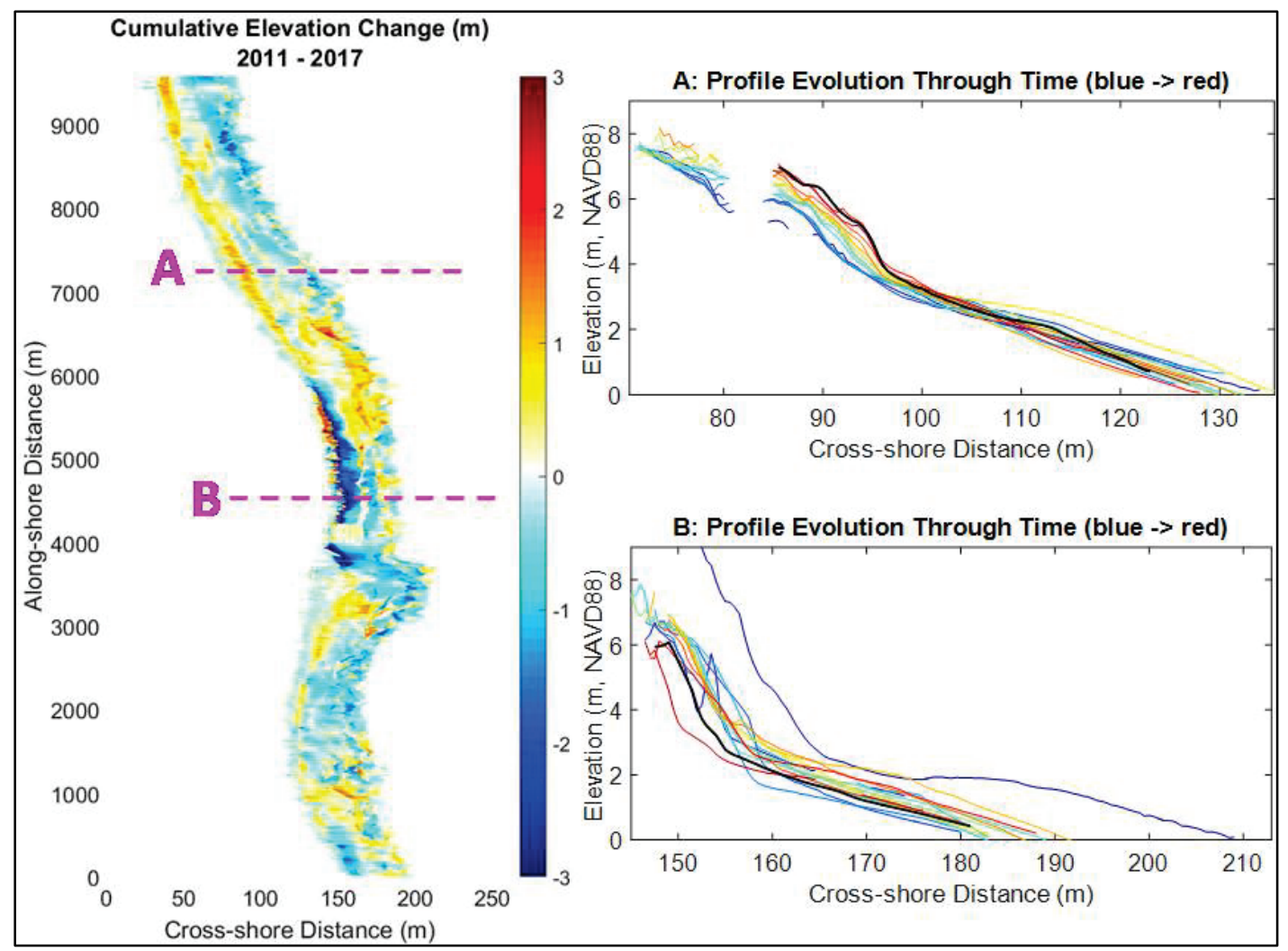

Alongshore averaged transect dune volume remained relatively stable throughout the region at $90-100 \mathrm{~m}^{3} / \mathrm{m}$, and average transect beach volume oscillated between $35-50 \mathrm{~m} 3 / \mathrm{m}$ (Figure 4-7). Average beach slope for the region fluctuated between -0.06 and -0.04 m/m (Figure 4-8). 
Figure 4-7. Average dune and beach volume for transects within the Duck beach segment. Dune volume was defined at each $2 \mathrm{~m}$ cross-shore transect as the area under the curve between dune crest and the $3 \mathrm{~m}$ contour. Beach volume defined as volume between the shoreline ( $1 \mathrm{~m}$ contour) and dune toe ( $3 \mathrm{~m}$ contour) for each $2 \mathrm{~m}$ wide transect.

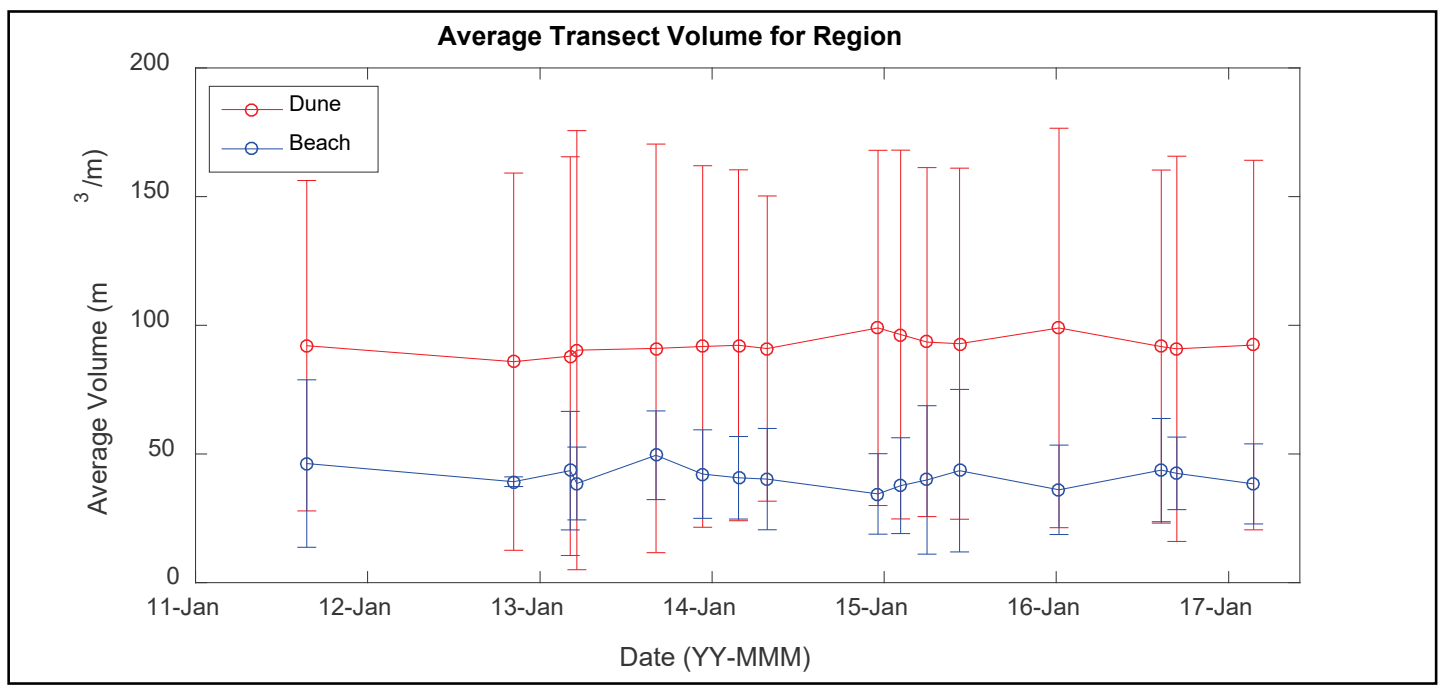

Figure 4-8. Average dune and beach slope for transects within the Duck beach survey segment. Beach slope was calculated between the dune tow $\left(D_{10}\right)$ defined at the $3 \mathrm{~m}$ contour and the shoreline, defined at the $1 \mathrm{~m}$ contour.

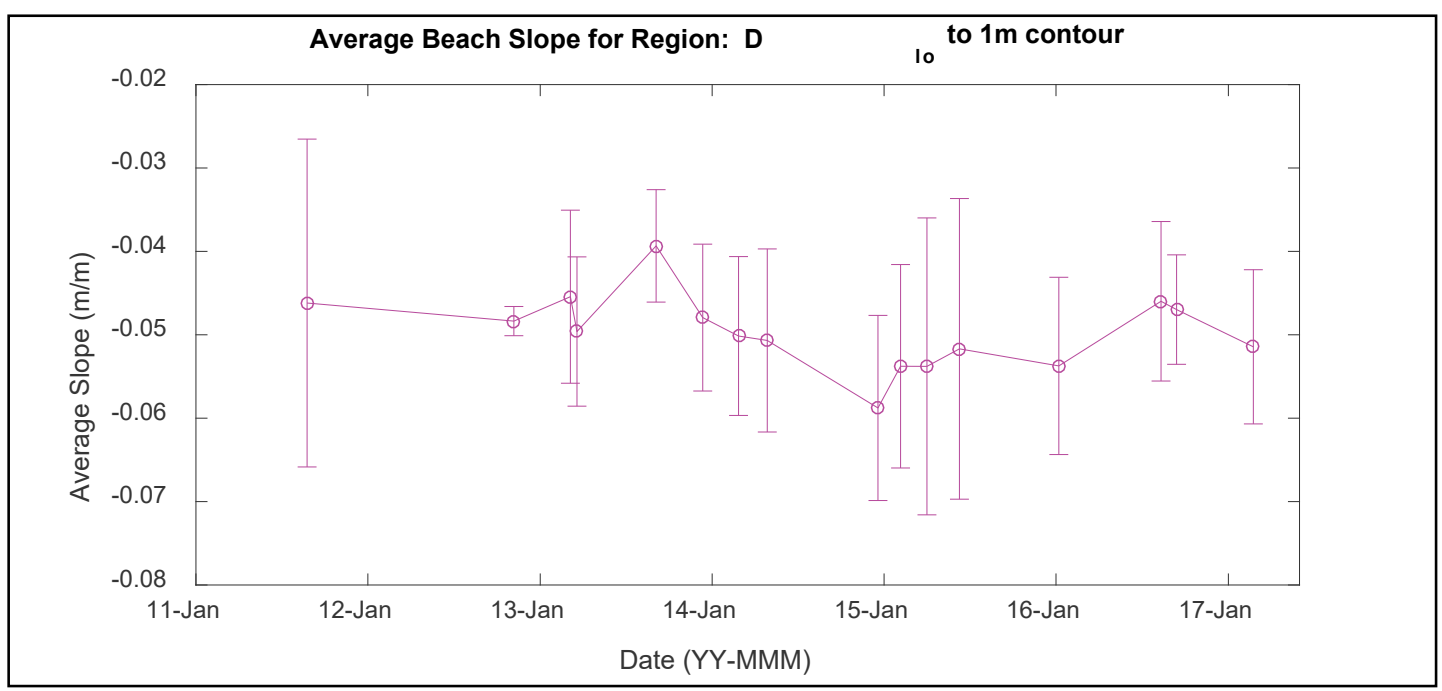

\subsubsection{Region 3: Southern Shores}

The Southern Shores region is adjacent to and south of the Duck region and is characterized by shallower along-shore embayment than the Corolla region. This area often exhibits much coarser grain size and along-shore beach cusps at various wavelengths dominate this region. A range of 10 to $20 \mathrm{~m}^{3}$ /year gains was observed in dune volume within the southern half of the region, and with less correlation and confidence, losses were observed 
in the northern half. Shoreline position trends exhibited low confidence in the linear fit, suggesting a high degree of variability in its position.

Figure 4-9. (left) Linear fit of dune volume change per year at each alongshore transect colored by the coefficient of determination $\left(R^{2}\right)$; (center) Average dune crest $\left(D_{h i}\right)$, dune toe

( $D_{1 \circ} 3 \mathrm{~m}$ contour), and shoreline (shore $1 \mathrm{~m}$ contour) cross-shore position with +/- one standard deviation shaded; legend at the bottom corresponds to the center panel; (right) Linear fit of shoreline cross-shore position change per year at each alongshore transect color by the coefficient of determination $\left(R^{2}\right)$. All panels correspond to the Southern Shores beach segment data of the northern Outer Banks surveyed by CLARIS.

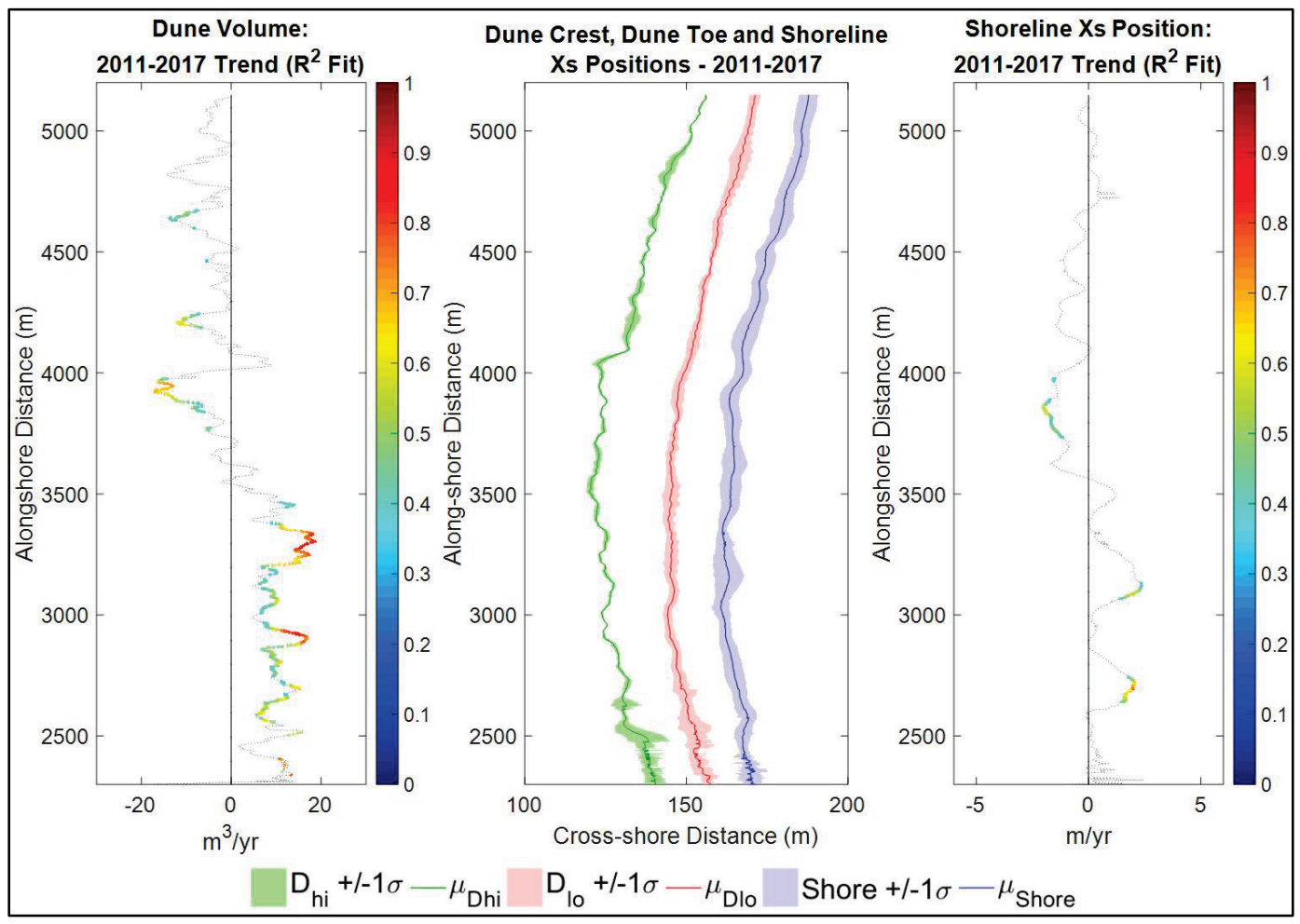

Cusp fields were frequently present and highly dynamic along this stretch of beach, identifiable in Figure 4-10 as the horizontal striations that mark the cumulative elevation change. The foredune was generally accretive along this region, with elevation gains approaching $1 \mathrm{~m}$ (e.g., Profile A, Figure 4-10). Beach elevation changes varied along-shore; in some locations the entire transect experienced accretion (e.g., Profile B, Figure 4-10). 
Figure 4-10. Cumulative elevation change along the Southern Shores beach segment of the northern Outer Banks between 2011 and 2017.

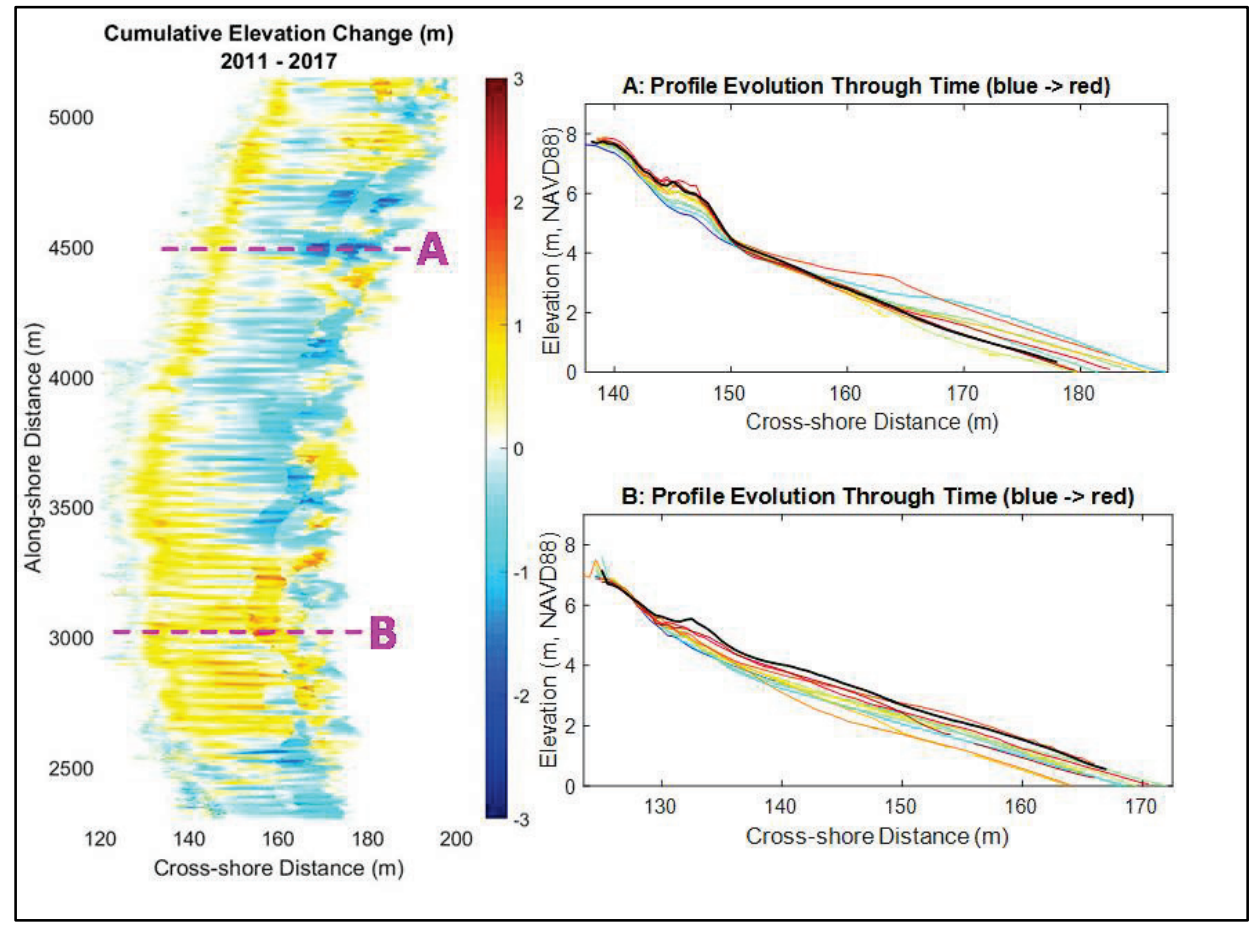

Average transect dune volume remained relatively stable throughout the region at 90-100 $\mathrm{m}^{3} / \mathrm{m}$, and average transect beach volume remained very stable, between 30-35 m3/m (Figure 4-11). Average beach slope for the region fluctuated between -0.065 and $-0.055 \mathrm{~m} / \mathrm{m}$ (Figure 4-12), the steepest beach slope amongst the three regions.

Figure 4-11. Average dune and beach volume for transects within the Southern Shores beach segment. Dune volume was defined at each $2 \mathrm{~m}$ cross-shore transect as the area under the curve between dune crest and the $3 \mathrm{~m}$ contour. Beach volume defined as volume between the shoreline ( $1 \mathrm{~m}$ contour) and dune toe ( $3 \mathrm{~m}$ contour) for each $2 \mathrm{~m}$ wide transect.

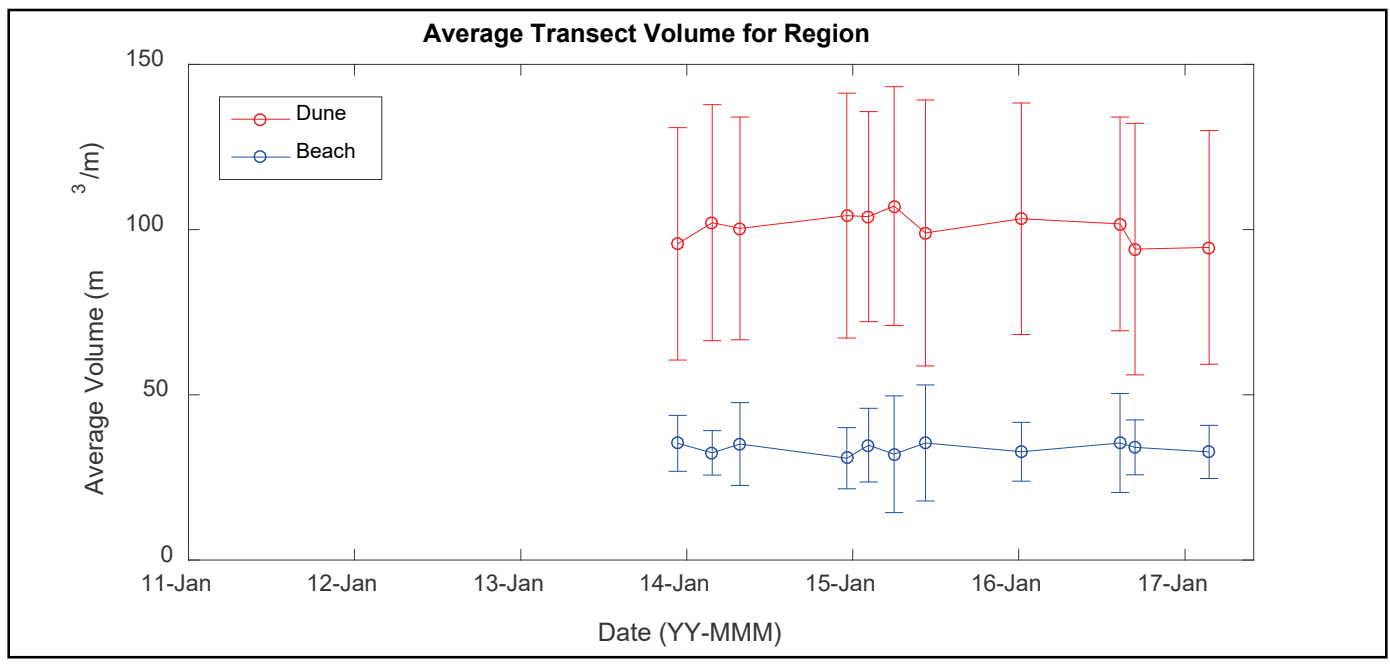


Figure 4-12. Average dune and beach slope for transects within the Southern Shores beach survey segment. Beach slope was calculated between the dune tow $\left(D_{\circ \circ}\right)$ defined at the $3 \mathrm{~m}$ contour and the shoreline, defined at the $1 \mathrm{~m}$ contour.

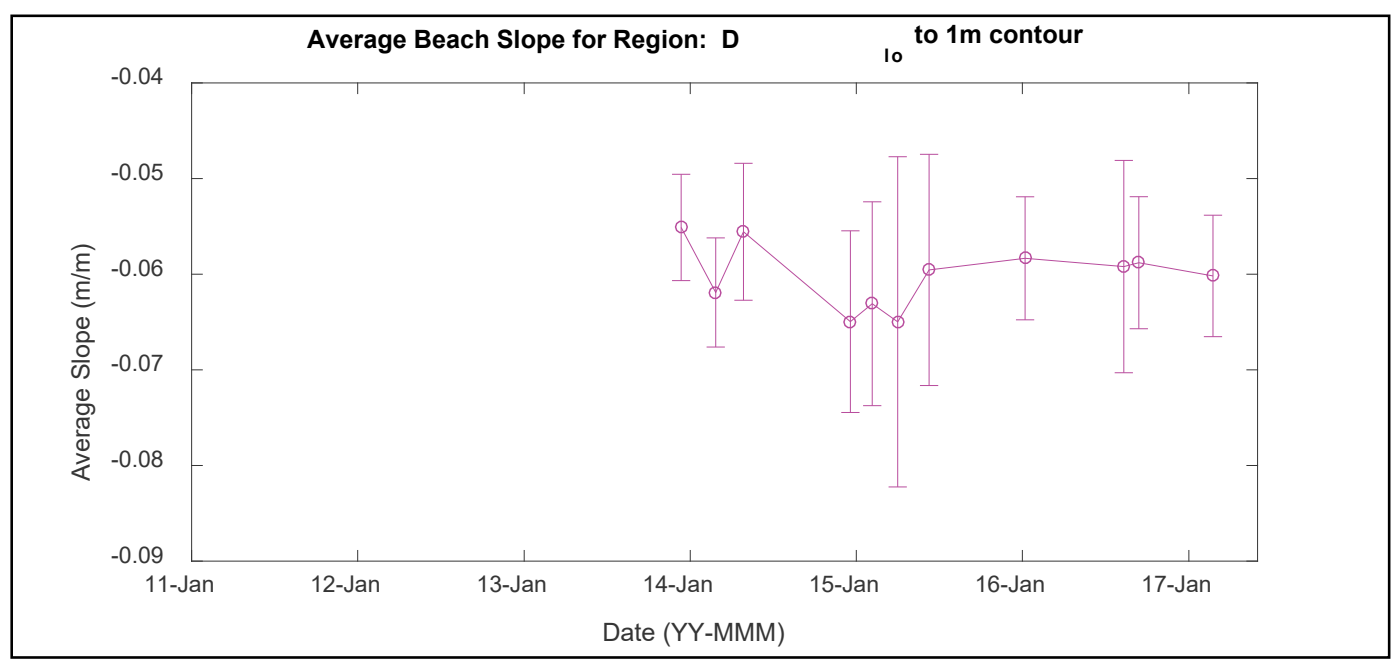

\subsubsection{Kitty Hawk/Kill Devil Hills}

While CLARIS data on the Kitty Hawk/Kill Devil Kills segment of shoreline are also available for portions of this time period, they are too sporadic for meaningful trends to be documented in this report (Figure 2-5).

\subsection{Data access}

The data described throughout this report are publicly available. All of the DEMs used for analysis have been converted into self-describing netCDF files that will be hosted on a THREDDS server at https://chlthredds.erdc.dren.mil/thredds/catalog/frf/geomorphology/mobile/catalog.html. As subsequent surveys are completed and the data are processed and quality controlled, future data will be uploaded. Classified .LAS files and associated metadata are hosted at the USACE Geospatial Repository and Data (GRiD) Management System and can be accessed at https://griduc.rsgis.erdc.dren.mil. 


\section{Conclusion}

\subsection{Summary}

This report summarizes available CLARIS data along the northern outer banks collected by the CHL between 2011 and 2017. CLARIS is a unique survey tool that can generate high-resolution point cloud data $(<0.1 \mathrm{~m}$ mean horizontal and vertical errors) at regional scales. By allowing for rapid data collections that demand minimal time and resources for preparation and deployment, CLARIS data may be realistically collected at semi-regular times as well as immediately before and after extreme events. This flexibility ensures that CLARIS data from the northern Outer Banks provide more than a sporadic snapshot of the coastal environment. Instead, these collections allow for detailed analysis of subaerial sediment budgets, sediment capture efficiency, beach/dune compartment exchange, and the development of other metrics of shoreline health.

\subsection{Next steps}

After the early 2017 survey (the last survey documented in this report), the CLARIS platform and instrumentation were upgraded. This transition includes the migration of the system from the Ford F350 to a Chevrolet Express 3500 passenger van. In addition to improved off-road driving capabilities and housing the majority of the system components within the climate-controlled cabin, new INS and TLS components allow for data collection in three-dimensional scanning mode. This scanning mode effectively doubles the survey extent for one tide cycle as both the dune and shoreline are scanned continuously as the vehicle advances forward (rather than requiring northbound and southbound passes).

Improvements to the radar components of the system will also produce synchronized time-series of radar data that will effectively track wave fronts as they propagate across the surf zone. By tracking these wave fronts, measurements of wave speed will be extracted and used within bathymetric inversion algorithms to infer the bathymetry.

This CLARIS platform upgrade was completed in time to monitor Dare County's first large-scale beach nourishment within Duck, Kitty Hawk, Southern Shores, and Kill Devil Hills. In 2017, over 4.1 million cubic yards of sand were placed along the beach by these municipalities in an attempt to mitigate widespread beach and dune erosion. Ludka et al. (2018) have 
demonstrated the value of examining nourishments at multiple beach placement sites through time to better understand the impacts of different environmental forcings within the same region. The timely upgrades made to the CLARIS system in 2017 will allow for the capture of the evolution of these placements at the regional scale. The next CLARIS data report will summarize data capturing changes within this modified system at an expanded scale. 


\section{References}

Berg, R. 2015. Tropical Cyclone Report: Hurricane Arthur (AL012014). National Hurricane Center.

Berg, R. 2016. Hurricane Joaquin (AL112015). National Hurricane Center tropical cyclone report. http://www. nhc. noaa. gov/data/tcr/AL112015_Joaquin.pdf

Birkemeier, W., R. Dolan, and N. Fisher. 1984. "The Evolution of a Barrier Island: 19301980." Shore and Beach 52(2): 3-12.

Birkemeier, W. 1985. "Field Data on Seaward Limit of Profile Change.” J. Waterway, Port, Coastal, Ocean Eng. 111: 598-602.

Birkemeier, W., H. Miller, S. Wilhelm, A. DeWall, and C. Gorbics. 1985. A User's Guide to the Coastal Engineering Research Center's (CERC's) Field Research Facility. Instruction Report CERC-85-1. Vicksburg, MS: U.S. Army Waterways Experiment Station.

Birkemeier, W. A., and K. T. Holland. 2001. "The Corps of Engineers' Field Research Facility: More than Two Decades of Coastal Research." Shore and Beach 69(1): 312.

Blake, E. S., T. B. Kimberlain, R. J. Berg, J. P. Cangialosi, and J. L. Beven II. 2013. Tropical Cyclone Report: Hurricane Sandy (AL182012), 22- 29 October 2012. National Hurricane Center. https://www.nhc.noaa.gov/data/tcr/AL182012_Sandy.pdf

Brock, J. C., and S. J. Purkis. 2009. "The Emerging Role of Lidar Remote Sensing in Coastal Research and Resource Management.” Journal of Coastal Research Special Issue 53: 1-5.

Brodie, K. L., T. Dyer, N. Spore, R. Slocum, A. O’Dea, T. Whitesides, and A. D. Renaud. 2018a. Continuously Operating Dune-Mounted Lidar System at the Field Research Facility: A Report Detailing Lidar Collection, Processing, Evaluation, and Product Development. ERDC/CHL SR-18-3. Vicksburg, MS: U.S. Army Corps of Engineers Research and Development Center.

Brodie, K. L., N. J. Spore, A. O’Dea, B. Raubenheimer, S. Elgar, and A. Albright. 2018b. Terrestrial Lidar Observations of Coastal Morphodynamics in Duck, NC. 2018 Ocean Sciences Meeting, 15 February 2018. https://agu.confex.com/agu/os18/meetingapp.cgi/Paper/314495

Brodie, K. L., and N. J. Spore. 2015. "Foredune Classification and Storm Response: Automated Analysis of Terrestrial Lidar DEMs." In The Proceedings of the Coastal Sediments 2015.

Brodie, K. L., B. Raubenheimer, S. Elgar, R. K. Slocum, and J. E. McNinch. 2015. "Lidar and Pressure Measurements of Inner-Surfzone Waves and Setup.” Journal of Atmospheric and Oceanic Technology 32(10): 1945-1959. 
Brodie, K. L., R. K. Slocum. and J. E. McNinch. 2012. "New Insights into the Physical Drivers of Wave Runup from a Continuously Operating Terrestrial Laser Scanner." Oceans 2012 IEEE: 1.

Coastal Planning \& Engineering of North Carolina, Inc. (CPE). 2015. Town of Duck, North Carolina, Erosion \& Shoreline Management Design Report. https://www.townofduck.com/beach-nourishment-project/monitoring-report/

Coastal Planning \& Engineering of North Carolina, Inc. (CPE). 2016. Town of Duck North Carolina Shoreline \& Volume Change Monitoring Report. https://obx.townofduck.com/wp-content/uploads/Town-of-Duck-2015-Monitoring-Report.pdf

Dolan, R., H. Lins, and B. Hayden. 1988. "Mid-Atlantic Coastal Storms.” Journal of Coastal Research 4(3): 417-433.

Earlie, C. S., G. Masselink, P. E. Russell, and R. K. Shail. 2015. "Application of Airborne LiDAR to Investigate Rates of Recession in Rocky Coast Environments.” Journal of Coastal Conservation 19(6): 831-45.

Eisemann, E. R., D. J. Wallace, M. C. Buijsman, and T. Pierce. 2018. "Response of a Vulnerable Barrier Island to Multi-Year Storm Impacts: LiDAR-Data-Inferred Morphodynamic Changes on Ship Island, Mississippi, USA.” Geomorphology 313: 58-71.

France, J. I., and W. Butler. 2012. "Mobile System Angular Alignment Quality Analysis." In Proceedings of American Society of Photogrammetry and Remote Sensing Conference (ASPRS 2012), Sacramento, CA, USA (Vol. 16).

Gares, P. A., Y. Wang, and S. A. White. 2006. "Using LIDAR to Monitor a Beach Nourishment Project at Wrightsville Beach, North Carolina, USA.” Journal of Coastal Research 22(5): 1206-1219.

Hayes, M. O. 1979. "Barrier Island Morphology as a Function of Tidal and Wave Regime." In Barrier Islands from the Gulf of Mexico to the Gulf of St. Lawrence. Edited by S. P. Leatherman. New York: Academic Press.

Hesp, P. 2002. "Foredunes and Blowouts: Initiation, Geomorphology and Dynamics." Geomorphology 48(1-3): 245-268.

Irish, J. L., and T. E. White. 1998. "Coastal Engineering Applications of High-Resolution Lidar Bathymetry.” Coastal Engineering 35(1-2): 47-71.

Lee, G. H., R. J. Nicholls, and W. A. Birkemeier. 1998. "Storm-Driven Variability of the Beach-Nearshore Profile at Duck, North Carolina, USA, 1981-1991.” Marine Geology 148(3): 163-177.

Le Mauff, B., M. Juigner, A. Ba, M. Robin, P. Launeau, and P. Fattal. 2018. "Coastal Monitoring Solutions of the Geomorphological Response of Beach-Dune Systems Using Multi-Temporal LiDAR Datasets (Vendée coast, France).” Geomorphology 304: 121-140.

Ludka, B., R. Guza, and W. O'Reilly. 2018. "Nourishment Evolution and Impacts at Four Southern California Beaches: A Sand Volume Analysis." Coastal Engineering 136: 96-105. 
McNinch, J. E., K. L. Brodie, H. M. Wadman, K. K. Hathaway, R. K. Slocum, R. P. Mulligan, J. L. Hanson, and W. A. Birkemeier. 2012. "Observations of Wave Runup, Shoreline Hotspot Erosion, and Sound-Side Seiching during Hurricane Irene at the Field Research Facility.” Shore \& Beach 8o(2): 19-37

Miselis, J., and J. McNinch. 2006. "Calculating Shoreline Erosion Potential Using Nearshore Stratigraphy and Sediment Volume: Outer Banks, North Carolina." Journal of Geophysical Research 111(F2).

O'Dea, A., K. L. Brodie, and P. Hartzell. 2019. "Continuous Coastal Monitoring with an Automated Terrestrial Lidar Scanner.” Journal of Marine Science and Engineering 7(2): 37 .

Pianca, C., R. Holman, and E. Siegle. 2015. "Shoreline Variability from Days to Decades: Results of Long-Term Video Imaging.” JGR Oceans 120(3): 2159-2178.

Pietro, L. S., M. A. O'neal, and J. A. Puleo. 2008. "Developing Terrestrial-LIDAR-Based Digital Elevation Models for Monitoring Beach Nourishment Performance." Journal of Coastal Research 24(6): 1555-1564.

Pye, K., and S. J. Blott. 2016. "Assessment of Beach and Dune Erosion and Accretion Using LiDAR: Impact of the Stormy 2013-14 Winter and Longer Term Trends on the Sefton Coast, UK.” Geomorphology 266: 146-167.

Rieger, P., N. Studnicka, M. Pfennigbauer, and G. Zach. 2010. "Boresight Alignment Method for Mobile Laser Scanning Systems.” Journal of Applied Geodesy 4(1): 13-21.

Robertson, Q., L. Dunkin, Z. Dong, J. Wozencraft, and K. Zhang. 2018. “Florida and US East Coast Beach Change Metrics Derived from LiDAR Data Utilizing ArcGIS Python Based Tools." In Beach Management Tools-Concepts, Methodologies and Case Studies, 239-258. Springer.

Safak, I., J. List, J. Warner, and N. Kumar. 2017. "Observations and 3D HydrodynamicsBased Modeling of Decadal-Scale Shoreline Change along the Outer Banks, North Carolina." Coastal Engineering 120: 78-92.

Sallenger, Jr., A. H., W. B. Krabill, R. N. Swift, J. Brock, J. List, M. Hansen, R. A. Holman, S. Manizade, J. Sontag, A. Meredith, and K. Morgan. 2003. "Evaluation of Airborne Topographic Lidar for Quantifying Beach Changes.” Journal of Coastal Research 19(1): 125-133.

Spore, N. J., and K. L. Brodie. 2017. Collection, Processing and Accuracy of Mobile Terrestrial Lidar Survey Data in the Coastal Environment. ERDC/CHL TR-17-5. Vicksburg, MS: U.S. Army Research and Development Center.

Stewart, S. R. 2017. National Hurricane Center Tropical Cyclone Report Hurricane Matthew (AL142016) 28 September-9 October 2016). National Hurricane Center. http://www.nhc.noaa.gov/data/tcr/AL142016_Matthew.pdf.

Sylvester, C. 2012. "Next-Generation Coastal Mapping to Further the National Ocean Enterprise.” In Oceans, 2012 1-8. 10.1109/OCEANS.2012.6404840 
Wozencraft, J. M., and W. J. Lillycrop. 2003. "SHOALS Airborne Coastal Mapping: Past, Present, and Future.” Journal of Coastal Research Special Issue 38: 207-215.

Young, A. P., M. J. Olsen, N. Driscoll, R. E. Flick, R. Gutierrez, R. T. Guza, E. Johnstone, and F. Kuester. 2010. "Comparison of Airborne and Terrestrial Lidar Estimates of Seacliff Erosion in Southern California." Photogrammetric Engineering \& Remote Sensing 76(4): 421-427. 


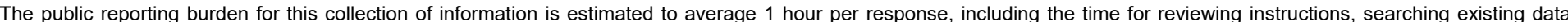

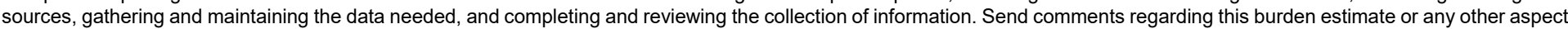

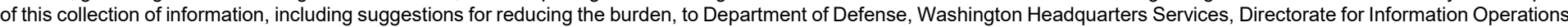

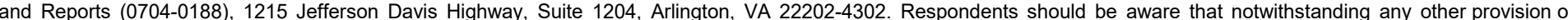
law, no person shall be subject to any penalty for failing to comply with a collection of information if it does not display a currently valid OMB control number. PLEASE DO NOT RETURN YOUR FORM TO THE ABOVE ADDRESS.

\begin{tabular}{l|l|l}
\hline $\begin{array}{l}\text { 1. REPORT DATE } \\
\text { July } 2019\end{array}$ & $\begin{array}{l}\text { 2. REPORT TYPE } \\
\text { Final Report }\end{array}$ & 3. DATES COVERED (FrOm - To)
\end{tabular}

\section{TITLE AND SUBTITLE}

Coastal Lidar and Radar Imaging System (CLARIS) Lidar Data Report: 2011 - 2017 5a. CONTRACT NUMBER

5b. GRANT NUMBER

5c. PROGRAM ELEMENT NUMBER

5d. PROJECT NUMBER

476930

Nicholas J. Spore, Alexander D. Renaud, Ian W. Conery, and Katherine L. Brodie

5e. TASK NUMBER

5f. WORK UNIT NUMBER

8. PERFORMING ORGANIZATION REPORT NUMBER

Coastal and Hydraulics Laboratory

U.S. Army Engineer Research and Development Center

1261 Duck Road

Duck, NC 27949

9. SPONSORING/MONITORING AGENCY NAME(S) AND ADDRESS(ES)

ERDC/CHL SR-19-4

Coastal Field Data Collection (CFDC) Program

U.S. Army Engineer Research and Development Center

Coastal and Hydraulics Laboratory

Vicksburg, MS 39180-6199

\section{DISTRIBUTION/AVAILABILITY STATEMENT}

Approved for public release; distribution is unlimited.

\section{SUPPLEMENTARY NOTES}

\section{ABSTRACT}

This U.S. Army Corps of Engineers data report documents available terrestrial lidar datasets collected by the U.S. Army Engineer Research and Development Center, Coastal and Hydraulics Laboratory (CHL), Coastal Lidar and Radar Imaging System between 2011 and 2017 along the northern Outer Banks of North Carolina near the CHL Field Research Facility. The report briefly describes the system and study site as well as the survey data extents, collection dates, and environmental context and data access information for the point cloud and digital elevation model products. Initial morphology data products and initial analyses are presented including calculations of shoreline change, dune volume, beach volume, beach slope, and cumulative elevation change over the 6-year study period. Follow-on reports will update the description of the available data repository moving forward.

\section{SUBJECT TERMS}

Coast changes - Computer simulation, Hydrodynamics, Ocean waves-Mathematical models, Sediment transport

\section{SECURITY CLASSIFICATION OF:}

\begin{tabular}{|l|c|l|}
\hline a. REPORT & b. ABSTRACT & c. THIS PAGE \\
Unclassified & Unclassified & Unclassified \\
\hline
\end{tabular}

17. LIMITATION OF ABSTRACT

SAR
18. NUMBER OF PAGES

49 19a. NAME OF RESPONSIBLE PERSON

19b. TELEPHONE NUMBER (Include area code) 